"This is the peer reviewed version of the following article: García del Cura, M. Ángeles y Calvo Sorando, José Pedro y Ordóñez Delgado, Salvador y Jones, Blair F. y Cañaveras, Juan Carlos (2001) Petrographic and geochemical evidence for the formation of primary, bacterially induced lacustrine dolomite: La Roda 'white earth' (Pliocene, central Spain). Sedimentology, 48 . pp. 897-915. ISSN 0037-0746, which has been published in final form at https://doi.org/10.1046/ j.1365-3091.2001.00388.x. This article may be used for non-commercial purposes in accordance with Wiley Terms and Conditions for Use of Self-Archived Versions."

\title{
Petrographic and geochemical evidence for the formation of primary, bacterially induced lacustrine dolomite: La Roda 'white earth' (Pliocene, central Spain)
}

\author{
M. ANGELES GARCíA DEL CURA*, JOSE P. CALVOt, SALVADOR ORDOÑEZt, \\ BLAIR F.JONES§ and JUANC.CAÑAVERASt \\ *Instituto de Geología Económica, CSIC-UCM, Madrid, Spain \\ tDpto Petrología y Geoquímica, Fac. CC. Geológicas, Universidad Complutense, Madrid, \\ Spain (E-mail: jpcalvo@eucmax.sim.ucm.es) \\ tDpto Ciencias de la Tierra y Medio Ambiente, Universidad de Alicante, Spain \\ §US Geological Survey, Reston, VA 22092, USA
}

\begin{abstract}
Upper Pliocene dolomites ('white earth') from La Roda, Spain, offer a good opportunity to evaluate the process of dolomite formation in lakes. The relatively young nature of the deposits could allow a link between dolomites precipitated in modern lake systems and those present in older lacustrine formations. The La Roda Mg-carbonates (dolomite unit) occur as a 3.5- to 4-m-thick package of poorly indurated, white, massive dolomite beds with interbedded thin deposits of porous carbonate displaying root and desiccation traces as well as local lenticular gypsum moulds. The massive dolomite beds consist mainly of loosely packed 1- to 2 - $\mu \mathrm{m}$-sized aggregates of dolomite crystals exhibiting poorly developed faces, which usually results in a subrounded morphology of the crystals. Minute rhombs of dolomite are sparse within the aggregates. Both knobbly textures and clumps of spherical bodies covering the crystal surfaces indicate that bacteria were involved in the formation of the dolomites. In addition, aggregates of euhedral dolomite crystals are usually present in some more clayey (sepiolite) interbeds. The thin porous carbonate (mostly dolomite) beds exhibit both euhedral and subrounded, bacterially induced dolomite crystals. The carbonate is mainly Ca-dolomite (51-54 $\mathrm{mol} \% \mathrm{CaCO}_{3}$ ), showing a low degree of ordering (degree of ordering ranges from 0.27 to $0 \cdot 48$ ). Calcite is present as a subordinate mineral in some samples. $\mathrm{Sr}, \mathrm{Mn}$ and $\mathrm{Fe}$ contents show very low correlation coefficients with $\mathrm{Mg} / \mathrm{Ca}$ ratios, whereas $\mathrm{SiO}_{2}$ and $\mathrm{K}$ contents are highly correlated. $\delta^{18} \mathrm{O}-$ and ${ }^{13} \mathrm{C}$-values in dolomites range from $-3.07 \%$ to $5 \cdot 40 \%$ PDB (mean=0.06, $\sigma=1 \cdot 75$ ) and from $-6 \cdot 34 \%$ to $-0.39 \%$ PDB (mean=-3.55, $\sigma=1.33$ ) respectively. Samples containing significant amounts of both dolomite and calcite do not in general show significant enrichment or depletion in ${ }^{18} \mathrm{O}$ and ${ }^{13} \mathrm{C}$ between the two minerals. The correlation coefficient between $\delta^{18} \mathrm{O}$ and $\delta^{13} \mathrm{C}$ for dolomite is extremely low and negative $(r=-0.05)$, whereas it is higher and positive $(r=0.47)$ for calcite. The lacustrine dolomite deposit from La Roda is interpreted mainly as a result of primary precipitation of dolomite in a shallow, hydrologically closed perennial lake. The lake was supplied by highly saturated $\mathrm{HCO}_{3}{ }^{-} / \mathrm{CO}_{3}{ }^{2-}$ groundwater that leached dolomitic Mesozoic formations. Precipitation of dolomite from alkaline lake waters took place under a semi-arid to arid climate. However, according to our isotopic data, strong evaporative conditions were not required for the formation of the La Roda dolomite. A significant contribution by bacteria to the formation of the dolomites is assumed in view of both petrographic and geochemical evidence
\end{abstract}

Keywords Dolomite, lacustrine deposits, petrography, Pliocene, Spain, stable isotopes. 


\section{INTRODUCTION}

Studies on the formation of sedimentary dolomite have been in continuous progression for several decades. Dolomitization processes in sedimentary rocks are a recurrent subject for petrologists and sedimentologists, as these processes take place in many distinct geological circumstances (for reviews of the 'dolomite problem' as well as dolomitization models, see Fairbridge, 1957; Zenger, 1972; Lippman, 1973; Morrow, 1982a, b; Land, 1985; Machel \& Mountjoy, 1986; Gunatilaka, 1987; Hardie, 1987; Tucker \& Wright, 1990; Arvidson \& Mackenzie, 1999). The famous statement by Chilingar et al. (1979) that 'there are dolomites and dolomites', also noted by Hardie (1987) in his critical review of dolomitization models, clearly testifies to the complexity of the formation patterns of dolomite in sedimentary environments and explains the controversy that is found in the literature (e.g. Zenger et al., 1980; Hardie, 1987). 0ccurrences of dolomite in both modern and ancient lakes provide opportunities to study the generation of dolomite. As Last (1990) points out, modern lake systems offer an excellent chance to improve our understanding of the hydrogeochemical constraints of dolomite formation, because of the varied chemistries and concentrations recognized in lake waters, which represent a much wider range of conditions than those for Mg-carbonates formed in marine environments. From nearly 50 reported occurrences of non-detrital lacustrine dolomite of Quaternary age, Last (1990) concluded that most of these occurrences formed under saline lake conditions, which is in agreement with previous statements by Eugster \& Hardie (1978), Eugster \& Kelts (1983) and Warren (1989). An additional conclusion is that many of the recent lakes in which dolomite is formed contain NaCl-type brines, also characterized by high carbonate alkalinities, an aspect emphasized by Hardie (1987), high Mg/Ca ratios (see also Muller et al., 1972) and commonly high sulphate concentrations. An important conclusion from Last's (1990) review of the recent lacustrine occurrences is that dolomite in lakes must be mostly primary. Yet, the results obtained from several studies monitored in recent south
Australian lakes (Rosen \& Coshell, 1992) do not seem to support such a primary origin for dolomite, so the exact mechanism of dolomite formation in lakes remains an open question.

Transferring these conclusions to dolomite formation in past lake systems is speculative. Even in sedimentary formations where dolomite has been classically studied, for instance the Eocene Green River Formation of western USA (Wolfbauer \& Surdam, 1974; Smoot, 1983), the origin of dolomite remains unclear. This paper presents a case study of lacustrine dolomite deposits from the Pliocene of central Spain, in which the relatively young nature of the dolomite allows determination of some aspects of the genetic pattern of dolomite in lakes. Good preservation of the La Roda dolomite deposits, which have not undergone significant burial diagenesis and have a powdery, non-indurated appearance, makes these materials suitable for such a goal. The study is supported by detailed petrography, mineralogy and geochemistry of the dolomite crystal mosaics and associated clays, the latter occurring whether disseminated within the dolomite or in thin beds between the carbonate sediments. Emphasis is placed on some features of the dolomite crystals that can be interpreted as resulting from microbial activity, this supporting the important role of biological factors controlling the formation of dolomite (Vasconcelos \& McKenzie, 1997; Wright, 1999).

\section{FIELD OCCURRENCE AND SAMPLE LOCATION}

The Pliocene lacustrine dolomite deposits are located in the vicinity of the village of La Roda, Albacete province, in central-east Spain (Fig. 1). They crop out on a flat-lying area surrounded by small exposures of Mesozoic rocks that constitute the substratum of the Neogene sediments. The dolomite deposits are known as 'white earth' in the region where they have traditionally been quarried to furnish local, but profitable, paint industries. The carbonate beds (dolomite unit), containing mainly dolomite and subordinate calcite, reach up to $4 \mathrm{~m}$ in thickness and are 

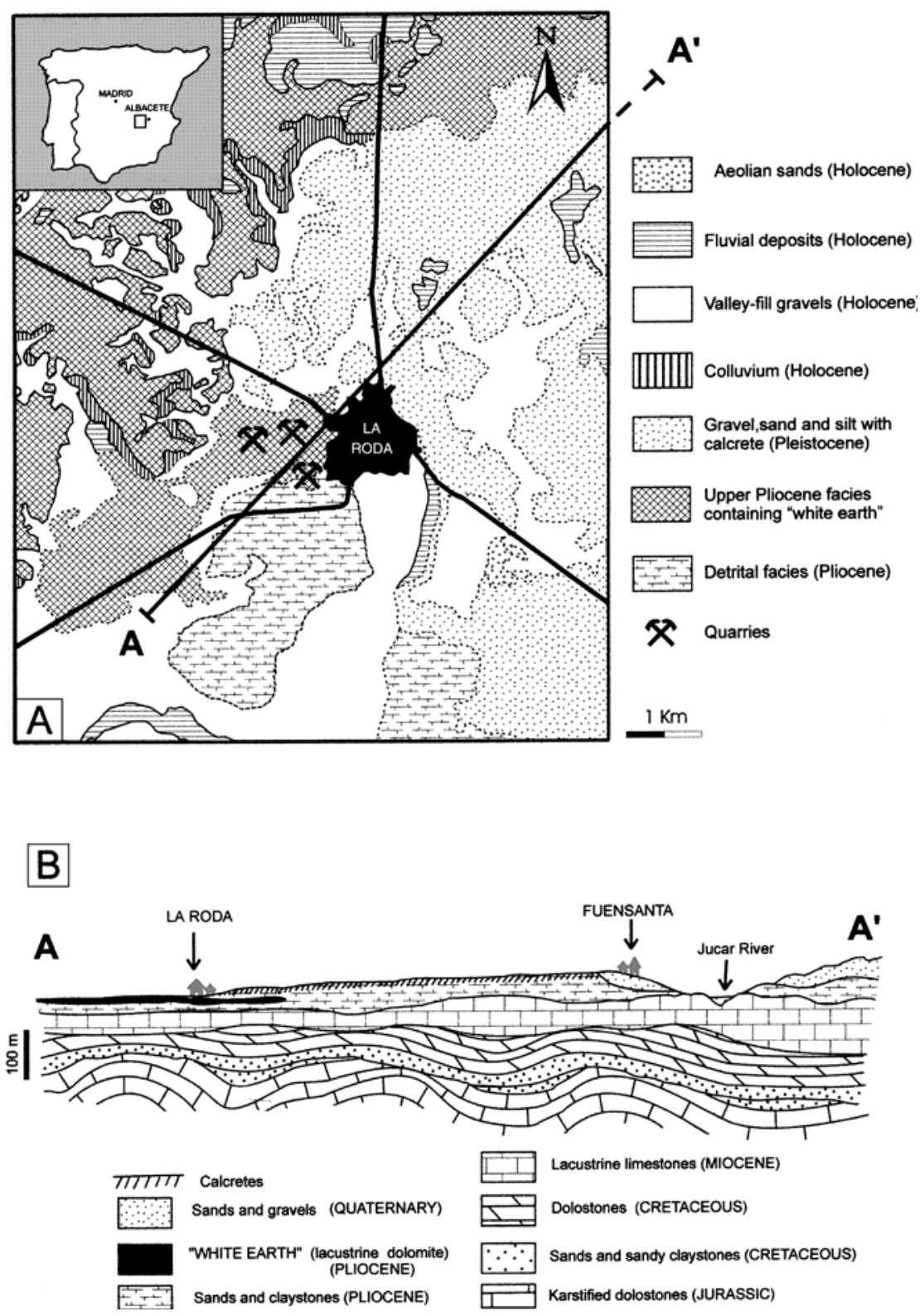

Fig. 1. Location of the La Roda lacustrine dolomite deposits. (A) Geological map of the study area; sampling of the dolomite sediments focused on the quarries west of La Roda. (B) Cross-section showing the distribution of the Pliocene dolomites and associated formations overlying Miocene and Mesozoic rocks; the section corresponds to the profile marked A-A' (which exceeds the extent of the map) in (A).

observed locally to overlie well-sorted, mediumto coarse-grained sands and mudstones of fluvial origin (Yebenes et al., 1973; Santos, 1983). The lacustrine carbonates are in turn covered by red to greenish laminated mudstones, which are interbedded with carbonate and show clear palustrine features (mudstone-limestone unit; Fig. 2). The mudstones, consisting mostly of illite and kaolinite with local smectite-rich horizons, show abundant pedogenic features, mainly root traces, calcite nodules with diffuse boundaries and drab haloes, whereas the carbonates comprise indurated calcretes and/or root-bioturbated biomicrite and calcareous marls (Fig. 3). These units of Late Pliocene age (Santos, 1983) are in turn covered unconformably by Pleistocene red gravel and sandstone beds in which calcrete profiles are broadly developed (Fig. 1).

Sampling was focused on six sections cropping out in a quarried area close to La Roda. Fifty-two samples were collected from the carbonate beds and associated terrigenous deposits in these sections. In outcrop, two main facies were distinguished within the carbonate sediments of the dolomite unit: (i) massive dolomites; and (ii) porous carbonates showing varied sedimentary features (Fig. 3). The porous carbonates show slightly less induration and are characterized by a grainy and crumbly appearance resulting from either a rather dense network of small holes of 


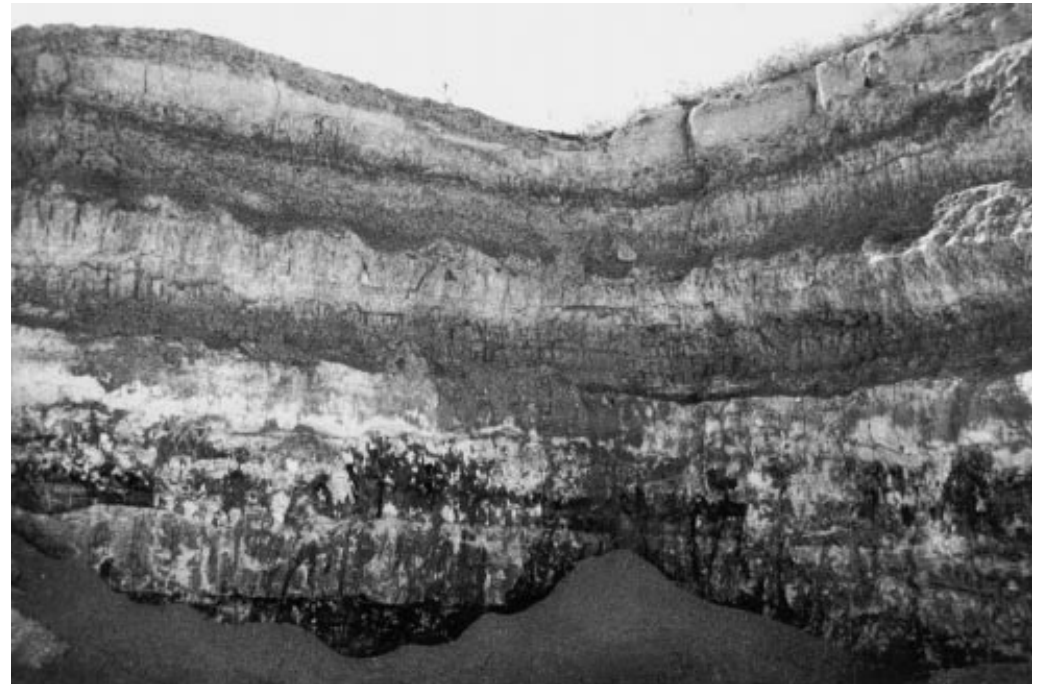

Fig. 2. Outcrop view of the deposits belonging to the dolomite unit (white beds, locally showing surficial dark stain because of organic patina at the lower part of the photograph) overlain by a sequence of interbedded mudstone and carbonates (mudstone-limestone unit) near La Roda. Note that the carbonate beds show a typical vertical prismatic structure characteristic of palustrine environments. The outcrop, reaching up $6 \mathrm{~m}$ in height, corresponds to section VI in Fig. 3.

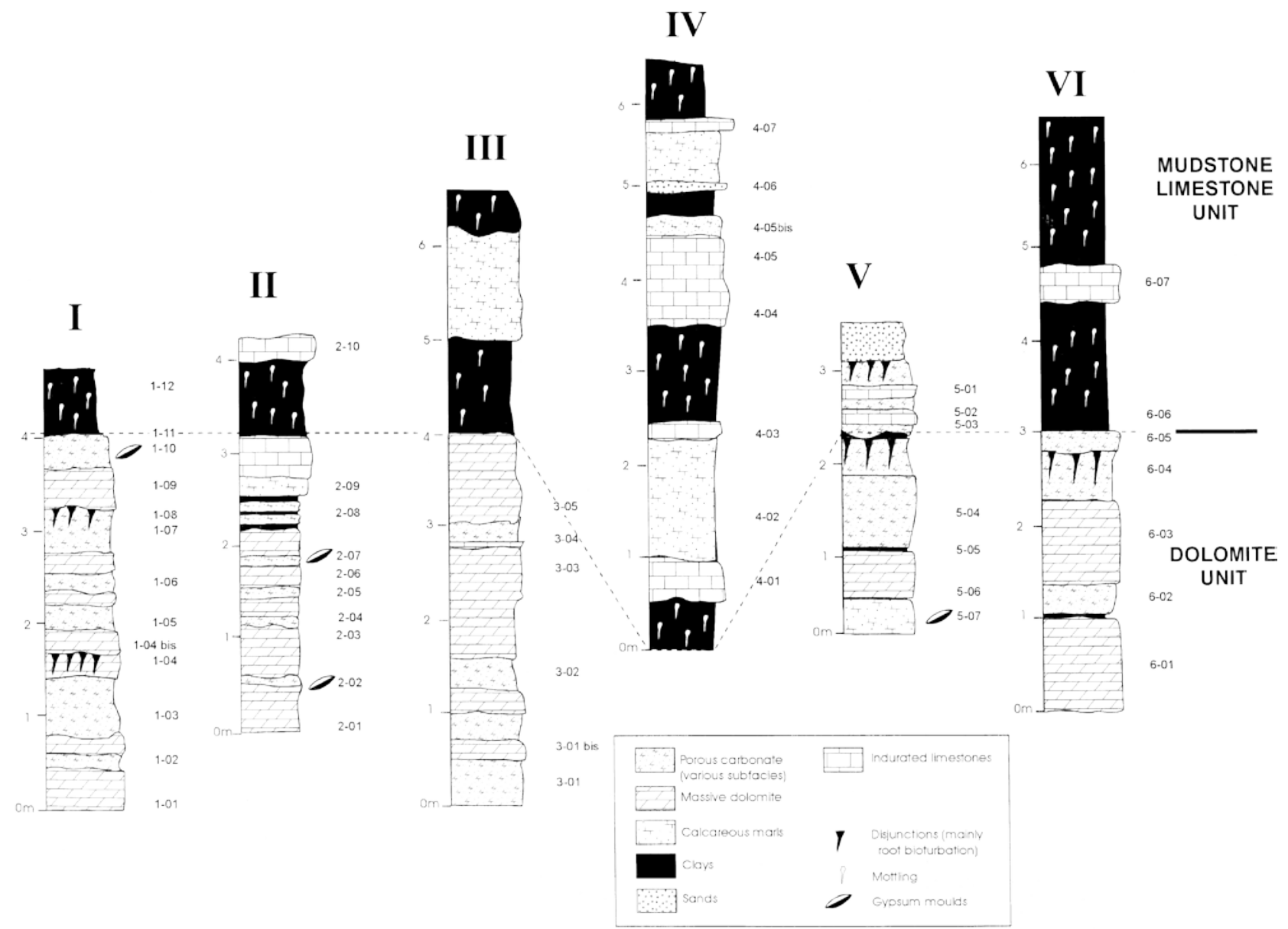

Fig. 3. Correlation lihostratigraphic sketch of the Pliocene sediments at La Roda. The correlation level marks the separation between lacustrine dolomite (white earth deposits) and an overlying interbedded mudstone and freshwater limestone unit; the latter unit is especially represented in logs III, IV and VI. Locations of samples listed in Table 1 are indicated.

various morphologies or lenticular gypsum moulds ranging from $0 \cdot 04 \mathrm{~mm}$ to $2 \mathrm{~mm}$ in length. The porous carbonate deposits are interbedded with more massive, white dolomite deposits of variable thickness, ranging from $1 \mathrm{dm}$ to $1 \mathrm{~m}$. Both the porous carbonates and the massive 
dolomites exhibit local vertical disjunction in the top beds. Calcite is also present as coarse crystalline aggregates filling cracks within the dolomite groundmass, giving way to a reticulate structure, as well as occluding voids in the porous carbonate. Clays, mixed with carbonate in some thin interbeds, are prominent at several levels of the sections, although they commonly occur disseminated within the dolomite. The clays consist mainly of sepiolite fibres, as described below. Terrigenous grains, mainly quartz and mica, are scarce in the dolomite beds.

\section{ANALYTICAL METHODS}

All samples were systematically analysed by standard petrography and scanning electron microscope (SEM) imaging (Jeol JSM-6400 and Hitachi 5400 field transmission apparatus). Alizarin red S stain of thin sections (Lindholm \& Finkelman, 1972) posed severe problems for petrographic differentiation of dolomite, as the minute crystals of this mineral also became stained, thus preventing a reliable view of the mineralogical distribution of the dolomite in the carbonate samples. This problem was partially solved by obtaining polished slabs coated with carbon, which were then observed under SEM (backscattered electron mode).

$\mathrm{X}$-ray diffraction was used to determine mineral composition in powdered carbonate samples and insoluble residues, using quartz as an internal standard. The equipment used was a Philips $\mathrm{X}$-ray diffraction system operated at $40 \mathrm{kV}$ and $30 \mathrm{~mA}$, and monochromated $\mathrm{Cu}-\mathrm{K}_{\mathrm{cx}}$ radiation. Semi-quantitative estimates of relative percentages of minerals from whole-rock samples were made through measurement of the intensity of the diffraction peaks by integration of the area. Values of mol\% $\mathrm{CaCO}_{3}$ of the carbonate minerals were estimated by measurement of the position of the $\mathrm{d}_{104}$ peak relative to a standard (Goldsmith et al., 1961). The degree of ordering of the dolomite crystals was determined by the sharpness and relative intensities of the ordering peaks, superstructure reflections corresponding to $\mathrm{d}_{021}$, $\mathrm{d}_{015}$ and $\mathrm{d}_{110}$ (Goldsmith \& Graf, 1958). The degree of ordering is thus estimated by the ratio of the heights of the ordering peak 015 to diffraction peak 110 (Hardy \& Tucker, 1988).

The clay minerals of samples containing a significant percentage of clay fraction $(>30 \%$ of the powdered whole rock) were analysed using oriented aggregates of the $<2-\mathrm{mm}$ fraction. They were treated with ethylene glycol and heated at $550{ }^{\circ} \mathrm{C}$ for $2 \mathrm{~h}$.

Major and trace element contents ( $\mathrm{Ca}, \mathrm{Mg}, \mathrm{Sr}$, $\mathrm{Fe}, \mathrm{Mn}, \mathrm{K}$ ) from whole-rock samples collected in one of the sections (section I, Fig. 3) were determined by X-ray fluorescence using standard techniques (Franzini et al., 1972, 1976) and by energy-dispersive spectrometry (EDS) in samples observed under SEM. The silica content was determined by the same method. For stable isotopic analysis, 40 samples were ground to pass through a 100-mesh sieve; the 250-mesh fraction was saved for analysis. Five of these samples correspond to limestones (exclusively formed of calcite) collected from beds of the mudstonelimestone unit in order to compare their isotopic signatures with those of the dolomites. For mixed carbonate samples, both calcite and dolomite were analysed if the lesser mineral constituted at least $10 \%$ of the total carbonate; otherwise, only the dominant mineral was analysed. Carbon dioxide was evolved from each sample at $25{ }^{\circ} \mathrm{C}$ using $100 \% \mathrm{H}_{3} \mathrm{PO}_{4}$. The gas evolved in the first hour was attributed to calcite; the gas evolved between $24 \mathrm{~h}$ and 7 days was attributed to dolomite. All samples were prepared and analysed at least in duplicate. The analytical precision is generally $\pm 0 \cdot 10 \%$ o for carbon and $\pm 0 \cdot 15 \%$ o for oxygen. 0xygen values were initially reported in permil relative to SMOW and then converted to PDB using the equation $\delta^{18} \mathrm{PDB}=0.97006 \delta^{18}$ SMOW - 29.94 (Craig, 1957).

\section{RESULTS}

\section{Petrography}

As mentioned previously, two main carbonate lithofacies were distinguished in the dolomite unit: massive dolomite and porous carbonate deposits, the latter showing a grainy and crumbly appearance (Fig. 3). Under the petrographic microscope, the massive dolomite is seen as a rather homogeneous micrite with sparse quartz, feldspar and mica grains (Fig. 4A) in which small elongate holes can be recognized very locally. In contrast, the porous carbonate deposits show a variety of petrographic features, which allow the distinction of three main subfacies types: (i) dolomicrite containing moulds of lenticular gypsum, in most cases filled by calcite spar; (ii) dolomicrite with abundant desiccation cracks and fissures related to small roots, locally preserving alveolar textures; and (iii) dolomicrite with scattered plant 

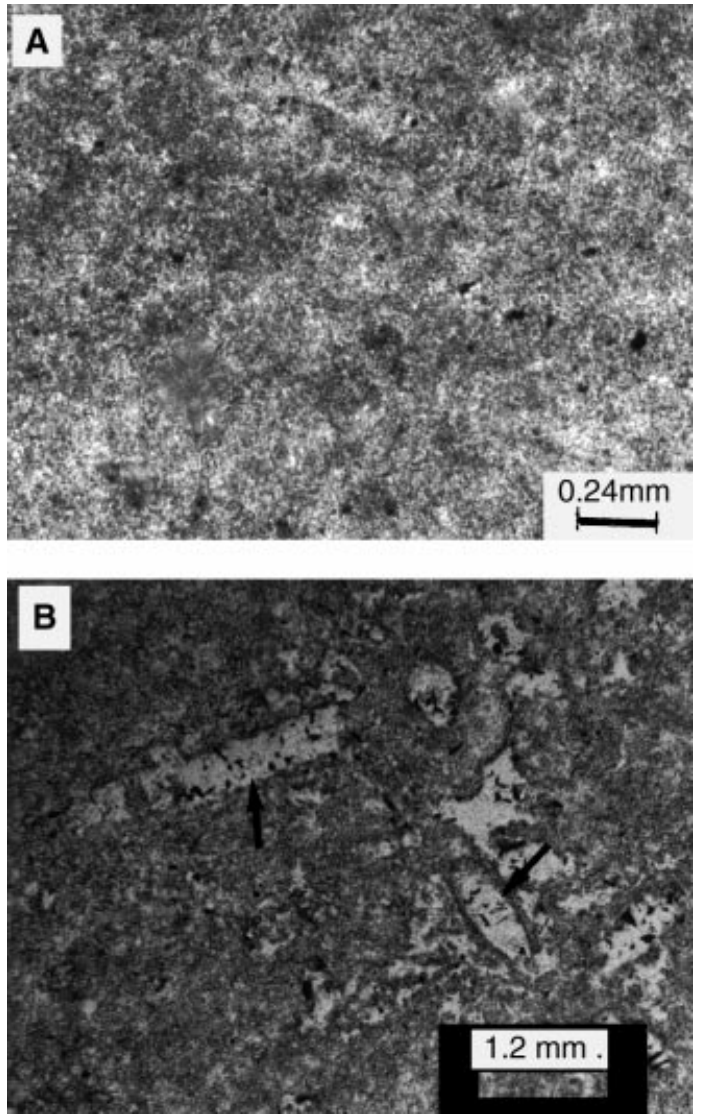

Fig. 4. Photomicrographs showing the textural characteristics of (A) massive dolomite deposits and (B) one of the subfacies distinguished within porous carbonate deposits. This subfacies corresponds to dolomicrite with scattered plant remains (arrows) encrusted by carbonate that, where more concentrated, gives a tufalike aspect to the deposit.

remains (Fig. 4B) and occasional charophyte stems and oogonia, the latter being poorly preserved or usually as moulds in the micrite groundmass. Calcite is locally abundant in some porous carbonate layers (samples 5-05 and 5-07; Table 1) where it is present as either veins formed by root bioturbation or rather dense aggregates of calcite-filled moulds after gypsum lenses.

SEM of whole-rock samples shows that the massive dolomite consists mainly of loosely packed crystalline aggregates, $1-2 \mu \mathrm{m}$ in size, with irregular morphologies (Fig. 5A). In detail, each of these aggregates is typically composed of interpenetrating submicron-sized dolomite rhombs (Fig. 5B), similar to those described by Talbot \& Kelts (1986) from recent sediments in Lake Bosumtwi. Besides this common appearance of the crystals in the massive dolomite deposit, some samples consist of crystalline aggregates, similar in size to those described before, showing widely extended clumps of spherical to ovate-shaped bodies, $0 \cdot 1-0 \cdot 3 \mu \mathrm{m}$ in size, resembling bacteria or nannobacteria (Rosen \& Coshell, 1992; Folk, 1993; Fig. 5C). Highly magnified SEM images allow the recognition of well-defined crystalline aggregates with a knobbly surface texture (Fig. 5D). In some clay-rich layers present within the massive dolomite deposits, the dolomite is made of both rhombic and subrhombic, up to 1-mm-diameter crystals mixed with clay mineral fibres (sepiolite), resulting in a largely open fabric (Fig. 5E), perhaps caused by nannobacteria. In detail, some of the dolomite crystals have multiple sharply defined edges, which suggests several growth episodes of the crystals (Fig. 5F).

The porous carbonate deposits show a variety of crystalline fabrics under SEM, which is coincident with the various subfacies types recognized in these deposits (see above). SEM images of dolomicrite containing moulds of lenticular gypsum show that the dolomite crystals, up to $1 \mathrm{~mm}$ in diameter, are typically rhombic and display multiple growth faces. Dolomicrites containing plant remains or showing abundant desiccation cracks do not have significant textural differences, and both subfacies types consist of either euhedral rhombic dolomite crystals or aggregates of subrounded crystals that are arranged according to circular (Fig. 6A) and/or rod-like (Fig. 6B) patterns.

\section{Mineralogy}

The Upper Pliocene carbonate sediments from La Roda have varied mineralogical compositions (Table 1 ), which are very clearly distinguishable when the two stratigraphic units present in the area are compared. Thus, carbonate from the mudstone-limestone unit consists of indurated limestones formed only of calcite (average $1.3 \mathrm{~mol} \% \mathrm{MgCO}_{3}$ ). In contrast, the dolomite unit comprises two carbonate lithofacies types (massive dolomite and porous carbonate) in which the carbonate mineral fraction is mostly dolomite. This mineral exceeds $90 \%$ in most of the samples characterized as massive dolomite. Calcite is present in variable proportions in some samples from both the massive dolomite and the interbedded porous carbonate. The degree of ordering in the richest dolomite samples, determined by measurement of indices 015 and 110 from X-ray traces, ranges from 0.27 to 0.48 (mean $=0.36$; Table 1), indicating that the dolomites are poorly ordered (Kinsman, 1964, cited in Bathurst, 1975). 
Table 1. Mineralogical and stable isotope composition of the La Roda carbonates and associated sediments (see Fig. 3 for sample locations).

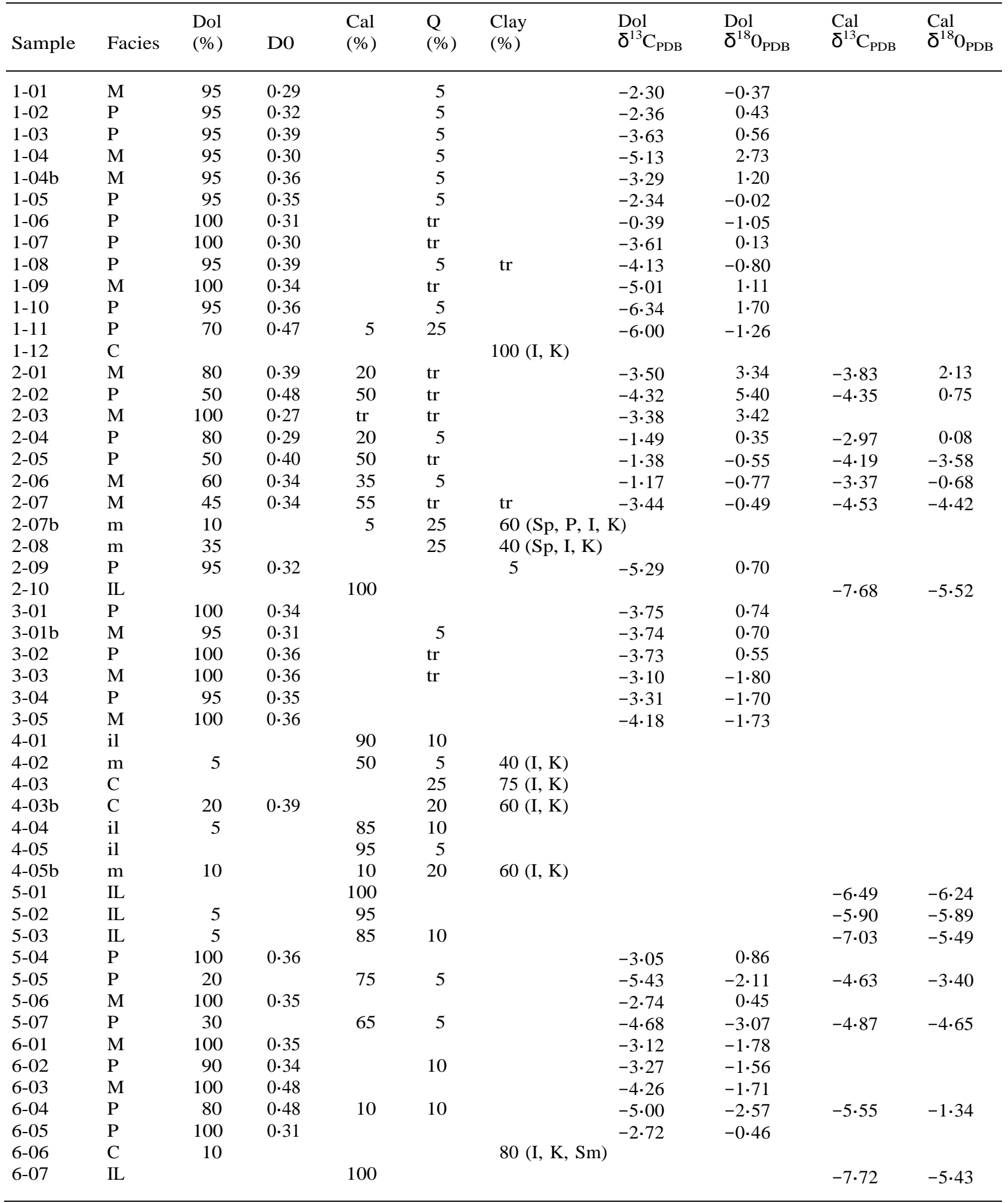

Codes for facies: M, massive dolomite; P, porous carbonate; C, clay deposits; m, marl; IL, indurated limestone. Clay minerals: I, illite; K, kaolinite; Sp, sepiolite; P, palygorskite; Sm, smectite. tr, trace $(<5 \%)$; D0, degree of ordering. 

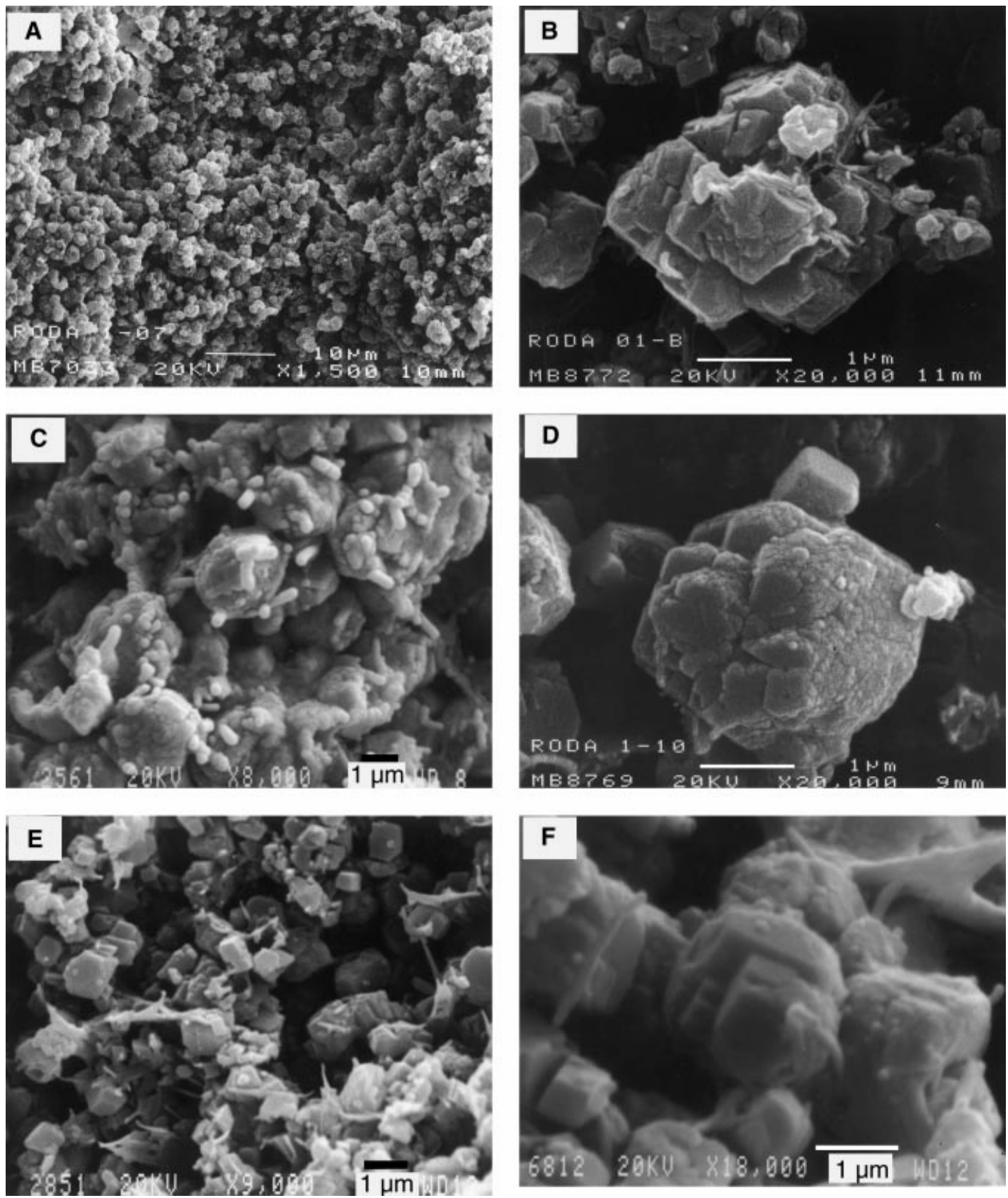

Fig. 5. SEM photomicrographs of textural features shown by the massive dolomites. (A) Loosely packed 1- to 2- $\mu$ msized dolomite crystal aggregates, which constitute the most typical fabric of the massive dolomites. (B) Enlarged view of one of the dolomite aggregates, typically composed of interpenetrating submicron-sized dolomite rhombs, resulting in a subrounded irregular morphology; note small sepiolite fibres mixed with the dolomite. (C) 2- $\mu$ m-sized, subrounded dolomite aggregates displaying abundant clumps of both spherical and oblong-shaped bodies resembling bacteria corpuscles. (D) Magnified view of a dolomite aggregate showing a rather regular morphology characterized by a knobbly surface texture in which abundant nannobacteria can be observed. (E) Rhombic to subrhombic, approximately 1- $\mu \mathrm{m}$-sized dolomite crystals typical of some beds rich in sepiolite (observable as sparsely distributed fibres within the dolomite fabric). (F) Enlarged view of a subrhombic dolomite aggregate showing multiple sharply defined edges; small spherical bodies (nannobacteria?) cover some crystals.

According to the mol\% $\mathrm{CaCO}_{3}$ values determined in the dolomites $\left(51-54 \mathrm{~mol} \% \mathrm{CaCO}_{3}\right)$, these can be characterized as slightly Ca-rich. Moreover, an inverse relationship between calcium content in the dolomite and their degree of ordering $\left(\mathrm{D} 0=-0.02\left[\mathrm{~mol} \% \mathrm{CaCO}_{3}\right]+1 \cdot 56\right)$ is observed, which is in agreement with that reported by Hardie (1987). 

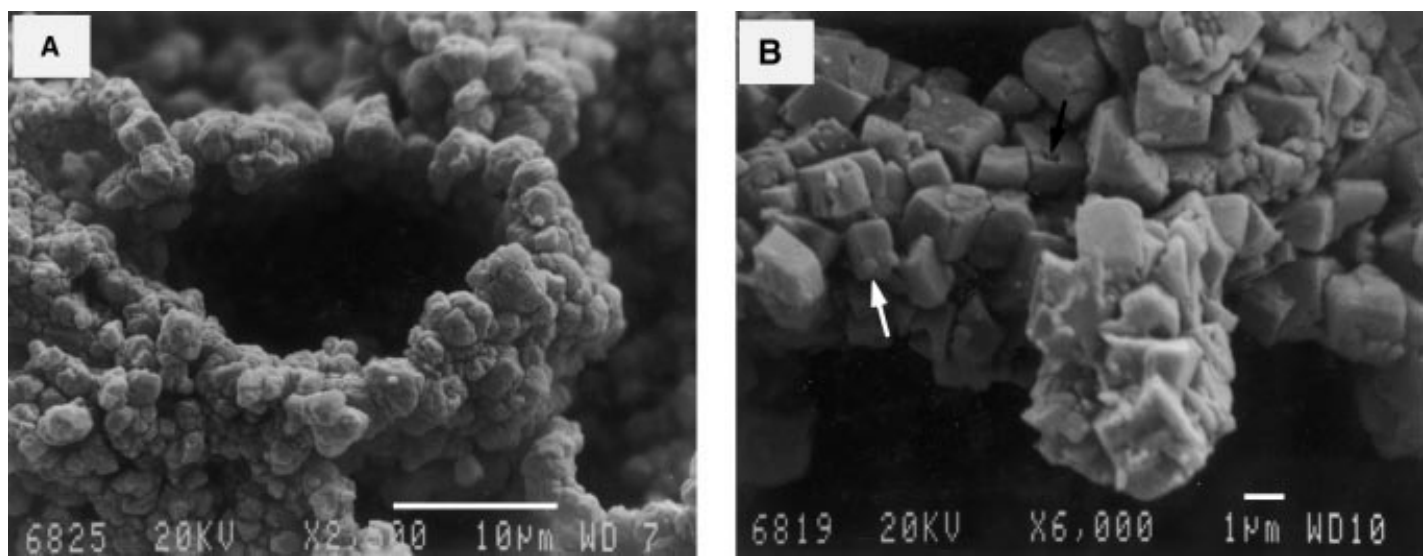

Fig. 6. SEM photomicrographs of textural features observed in porous carbonates. (A) Subrounded dolomite aggregates arranged in a circular pattern probably related to biogenic structures. (B) Rod-like arrangement of minute rhombic dolomite crystals; note that some crystals exhibit small dissolution holes (e.g. black arrow). Bacterial corpuscles are also seen in some dolomite crystals (e.g. white arrow).

The different carbonate mineralogy between the mudstone-limestone unit and the dolomite unit, together with the distinct sedimentary features observed in the two units, suggest a drastic change in the depositional conditions (see discussion below), which is also supported by the clay mineralogy. Clay minerals are relatively scarce within the massive dolomite and associated porous carbonate deposits, except for some thin clayey interbeds. The clay minerals determined in these facies consist predominantly of sepiolite (up to $75 \%$ of the clay fraction), with minor palygorskite and usually a low content of illite and kaolinite (Table 1). In contrast, the overlying mudstone-limestone unit contains beds in which clays constitute $30-80 \%$ of the bulk mineralogy. In these beds, illite is the dominant clay mineral together with kaolinite. The presence of smectite has only been recog- nized in one layer at the lowermost part of this unit.

Quartz is always present in significant percentages in the clay-marly beds of the mudstonelimestone unit, where feldspars are also observed only as traces. Quartz content in the dolomite unit is usually very low ("' $5 \%$ ) although quartz grains are relatively more abundant (up to $10 \%$ ) in porous carbonate beds than in the massive dolomites (Table 1).

\section{Geochemistry}

\section{Elements}

$\mathrm{Ca}, \mathrm{Mg}, \mathrm{Sr}, \mathrm{Mn}, \mathrm{Fe}, \mathrm{K}$ and silica contents from massive dolomites and associated porous carbonates were determined only in section I (Fig. 3, Table 2), which is representative of the various facies present in the La Roda carbonates. Ca, Mg,

Table 2. Chemical composition of dolomite samples from section I.

\begin{tabular}{llllllllll}
\hline Sample & $\mathrm{SiO}_{2}(\%)$ & $\mathrm{Ca} \mathrm{( \% )}$ & $\mathrm{Mg}(\%)$ & $\mathrm{Sr}(\mathrm{p} . \mathrm{p} \mathrm{m})$. & $\mathrm{Mn}(\mathrm{p} . \mathrm{p} \mathrm{m})$. & $\mathrm{Fe}(\%)$ & $\mathrm{K}(\%)$ & $\mathrm{Mg} / \mathrm{Ca}$ & $(\mathrm{Sr} / \mathrm{Ca}) \times 10^{4}$ \\
\hline $1-01$ & $1 \cdot 69$ & $25 \cdot 46$ & $9 \cdot 52$ & $834 \cdot 00$ & $0 \cdot 01$ & $0 \cdot 23$ & $0 \cdot 09$ & $0 \cdot 37$ & $32 \cdot 76$ \\
$1-02$ & $1 \cdot 53$ & $25 \cdot 21$ & $9 \cdot 73$ & $832 \cdot 00$ & $0 \cdot 01$ & $0 \cdot 23$ & $0 \cdot 07$ & $0 \cdot 39$ & $33 \cdot 01$ \\
$1-03$ & $2 \cdot 06$ & $24 \cdot 69$ & $10 \cdot 11$ & $600 \cdot 00$ & $0 \cdot 01$ & $0 \cdot 25$ & $0 \cdot 10$ & $0 \cdot 41$ & $24 \cdot 30$ \\
$1-04$ & $1 \cdot 37$ & $25 \cdot 03$ & $10 \cdot 15$ & $521 \cdot 00$ & $0 \cdot 01$ & $0 \cdot 20$ & $0 \cdot 07$ & $0 \cdot 41$ & $20 \cdot 82$ \\
$1-04 \mathrm{~b}$ & $1 \cdot 90$ & $24 \cdot 96$ & $9 \cdot 94$ & $692 \cdot 00$ & $0 \cdot 01$ & $0 \cdot 25$ & $0 \cdot 07$ & $0 \cdot 40$ & $27 \cdot 72$ \\
$1-05$ & $1 \cdot 90$ & $24 \cdot 94$ & $9 \cdot 99$ & $599 \cdot 00$ & $0 \cdot 01$ & $0 \cdot 30$ & $0 \cdot 07$ & $0 \cdot 40$ & $24 \cdot 02$ \\
$1-06$ & $0 \cdot 85$ & $25 \cdot 33$ & $10 \cdot 03$ & $730 \cdot 00$ & $0 \cdot 00$ & $0 \cdot 17$ & $0 \cdot 04$ & $0 \cdot 40$ & $28 \cdot 82$ \\
$1-07$ & $0 \cdot 92$ & $25 \cdot 19$ & $10 \cdot 10$ & $776 \cdot 00$ & $0 \cdot 01$ & $0 \cdot 20$ & $0 \cdot 03$ & $0 \cdot 40$ & $30 \cdot 81$ \\
$1-08$ & $7 \cdot 29$ & $22 \cdot 54$ & $9 \cdot 70$ & $494 \cdot 00$ & $0 \cdot 02$ & $1 \cdot 16$ & $0 \cdot 26$ & $0 \cdot 43$ & $21 \cdot 91$ \\
$1-09$ & $2 \cdot 16$ & $25 \cdot 23$ & $9 \cdot 60$ & $557 \cdot 00$ & $0 \cdot 03$ & $0 \cdot 40$ & $0 \cdot 13$ & $0 \cdot 38$ & $22 \cdot 08$ \\
$1-10$ & $2 \cdot 76$ & $24 \cdot 82$ & $9 \cdot 64$ & $570 \cdot 00$ & $0 \cdot 05$ & $0 \cdot 53$ & $0 \cdot 13$ & $0 \cdot 39$ & $22 \cdot 96$ \\
Mean & $2 \cdot 22$ & $24 \cdot 85$ & $9 \cdot 86$ & $655 \cdot 00$ & $0 \cdot 02$ & $0 \cdot 36$ & $0 \cdot 10$ & $0 \cdot 40$ & $26 \cdot 29$ \\
SD & $1 \cdot 77$ & $0 \cdot 80$ & $0 \cdot 23$ & $123 \cdot 24$ & $0 \cdot 01$ & $0 \cdot 29$ & $0 \cdot 06$ & $0 \cdot 02$ & $4 \cdot 50$ \\
& & & & & & & & \\
\hline
\end{tabular}


$\mathrm{Sr}$ and $\mathrm{Mn}$ were selected for analysis because of their significance in carbonate sedimentation and diagenesis, whereas $\mathrm{Fe}, \mathrm{K}$ and silica can help in reflecting the contribution of terrigenous input to the carbonate sediments. This latter assessment is clearly corroborated by plotting silica contents vs. $\mathrm{K}$ and $\mathrm{Fe}$ in separate binary diagrams (Fig. 7A and B). In both cases, the linear correlation is high, suggesting that $\mathrm{K}$ and $\mathrm{Fe}$ are intimately associated with silica forming aluminosilicates. $\mathrm{Sr}$ exhibits low (mean $=655$ p.p.m.) but fluctuating values
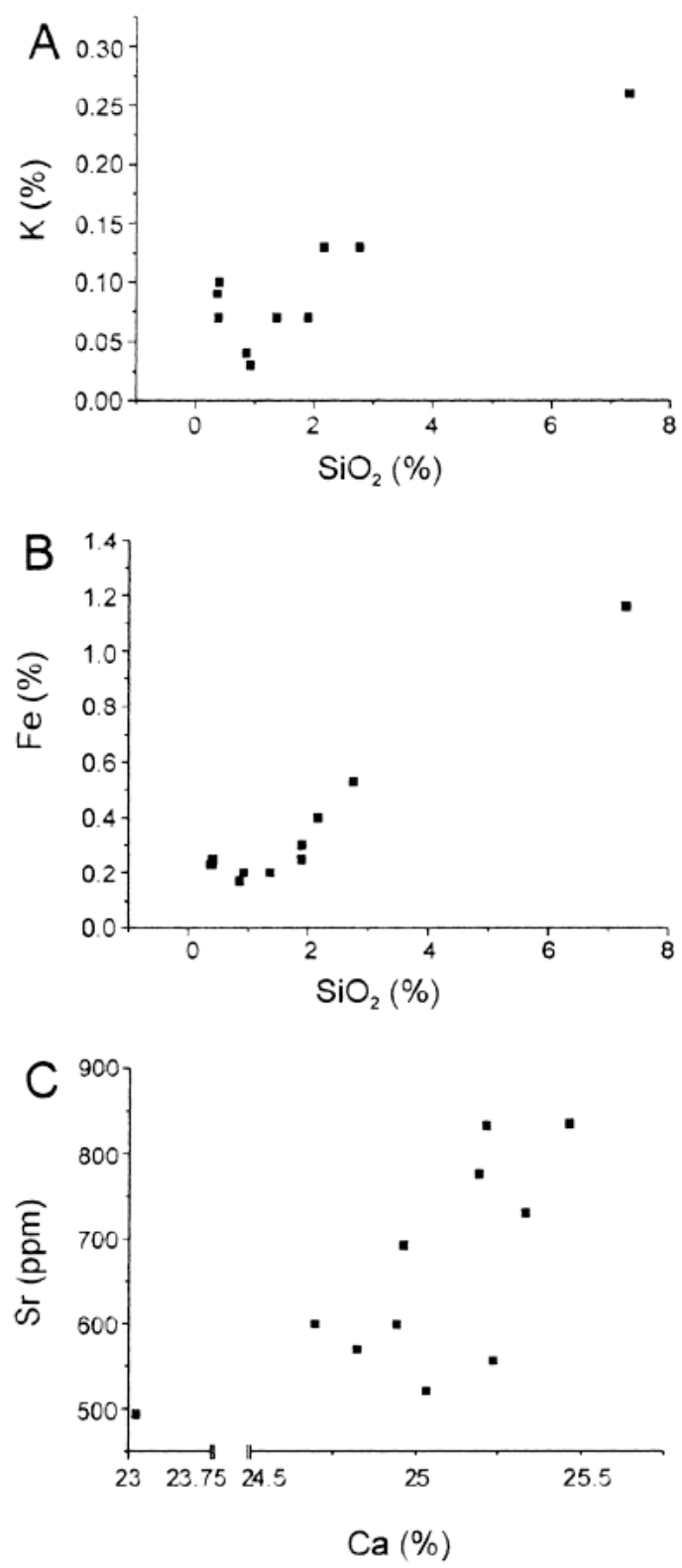

Fig. 7. Binary plots showing geochemical affinities between silica and $\mathrm{K}$ (A) and $\mathrm{Fe}$ (B) contents, and between $\mathrm{Ca}$ and $\mathrm{Sr}$ (C) contents in dolomite samples from section $\mathrm{I}$.
(Table 2) that show a rather good correlation with Ca contents (Fig. 7C), a behaviour that agrees with the findings of others that $\mathrm{Sr}$ substitutes for $\mathrm{Ca}$ rather than $\mathrm{Mg}$ in the dolomite lattice (Kretz, 1982). The distribution coefficients for $\mathrm{Sr}$ in dolomite $\left(K_{\text {dol }}^{\mathrm{Sr}}\right)$ are much lower than unity (Katz \& Matthews, 1977). Mn contents are generally very low (mean $=143$ p.p.m.), except for the uppermost part of the section, where the presence of pedogenic features is apparent (Fig. 3, Table 2). This relationship between higher Mn contents and pedogenic features appears to be supported by values of $\delta^{13} \mathrm{C}$ (Fig. 8A) determined in the carbonate samples.

$\mathrm{Mg}$ and $\mathrm{Ca}$ contents vary between $9.52 \%$ and $10 \cdot 15 \%$ and $22 \cdot 54 \%$ and $25 \cdot 46 \%$ respectively (Table 2). $\mathrm{Mg} / \mathrm{Ca}$ ratios fluctuate in a narrow interval (mean $=0.40 \pm 0.02$ ), which confirms the Ca-rich nature of the dolomites determined by calculations from X-ray traces. Moreover, $\mathrm{Mg} / \mathrm{Ca}$ ratios have been plotted vs. stable isotope signatures (Fig. 8) in order to establish palaeoenvironmental constraints on the formation of the lacustrine dolomite. A weak negative correlation is found between $\mathrm{Mg} / \mathrm{Ca}$ ratios and $\delta^{18} 0$ (Fig. 8D), which suggests that the formation of dolomite was not constrained by highly evaporative con- ditions (see discussion below). Likewise, $\mathrm{Mg} / \mathrm{Ca}$

ratios and $b^{13} C$ show a weak negative correlation (Fig. 8B).

\section{Stable isotopes}

Isotopic analysis was carried out on 40 carbonate samples from the different sections. The wholerock isotopic data from the lacustrine carbonates were used to help in environmental interpretations as well as in deriving valuable information about inorganic and/or organic constraints on the formation of dolomite. 0xygen and carbon isotopic ratios, expressed as $\delta^{18} 0_{\mathrm{PDB}}$ and $\delta^{13} \mathrm{C}_{\mathrm{PDB}}$ are listed in Table 1. Five samples (2-10, 5-01, 5-02, 5-03 and 6-07), collected from beds of the mudstone-limestone unit, were formed solely of calcite. A few samples (2-01, 2-02, 2-04, 2-05, 2-06, 2-07, 5-05, 5-07 and 6-04) contained sufficient calcite and dolomite for both to be analysed; all other analyses were only for dolomite. Samples containing both calcite and dolomite were studied under the petrographic microscope in order to identify the primary or (early or late) diagenetic character of calcite and thus to understand better the isotopic signatures obtained from these bimineralic samples. Calcite appears to be mainly a late diagenetic product, occurring either as 

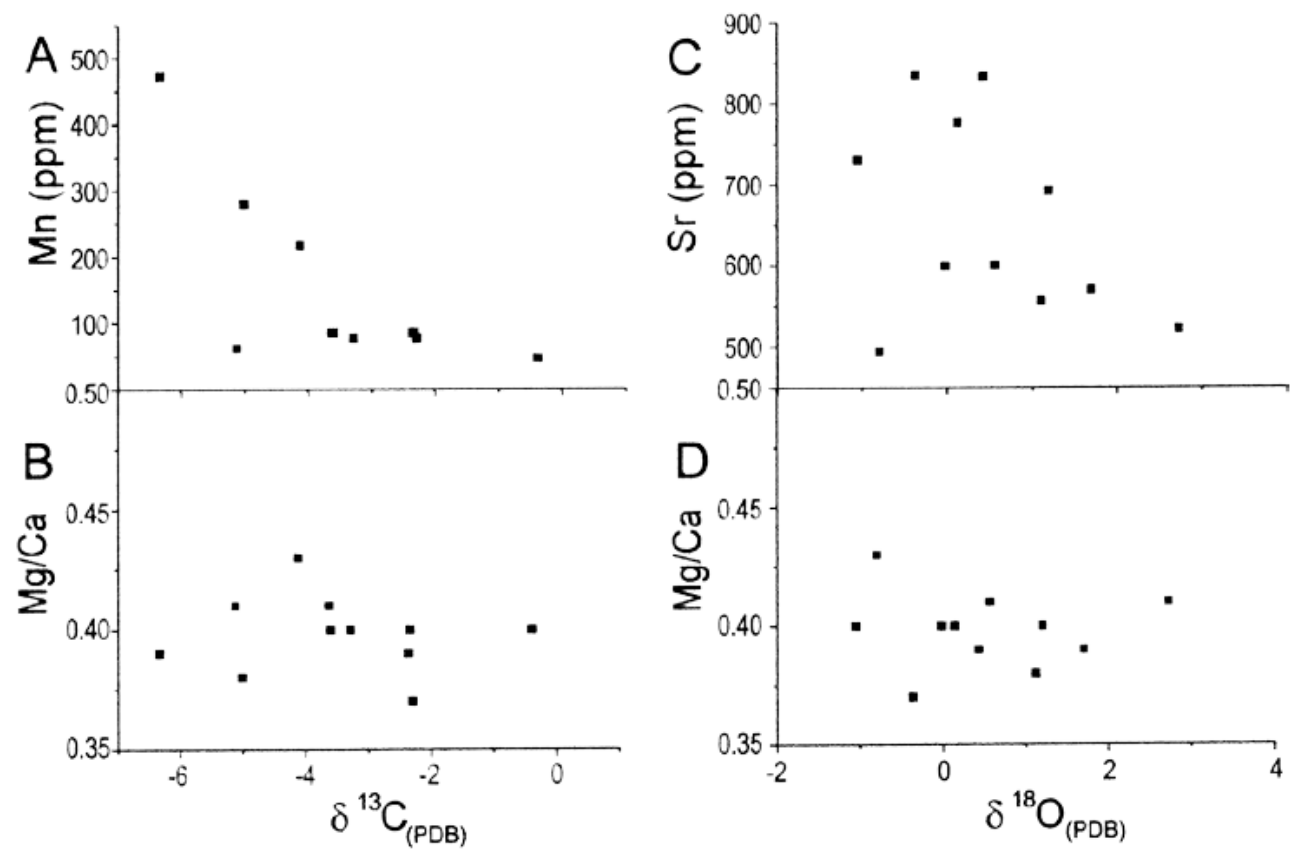

Fig. 8. Plots showing the relationships between several chemical element parameters of the dolomite samples and stable isotope compositions: (A) $\delta^{13} \mathrm{C}-\mathrm{Mn}$ showing a marked negative correlation; (B) $\mathrm{Mg} / \mathrm{Ca}$ vs. $\delta^{13} \mathrm{C}$ shows no correlation; (C) $\delta^{18} 0-\mathrm{Sr}$ showing some apparent negative correlation; (D) $\mathrm{Mg} / \mathrm{Ca}$ vs. $\delta^{18} 0$ shows no correlation.

cement partly filling voids (Fig. 9) or as calcite spar mosaic pseudomorphs of previous gypsum lenticles.

The isotopic compositions of the La Roda carbonates cover a broad range of negative $b^{13} \mathrm{C}$ values $(-7 \cdot 720$ to $-0 \cdot 390)$ and of both negative and positive $b^{18} 0$ values $(-6 \cdot 240$ to $+5 \cdot 400$; Table 1). When $b^{18} 0$ is plotted against $b^{13} \mathrm{C}$, a group of carbonates corresponding to indurated limestones from the mudstone-limestone unit is

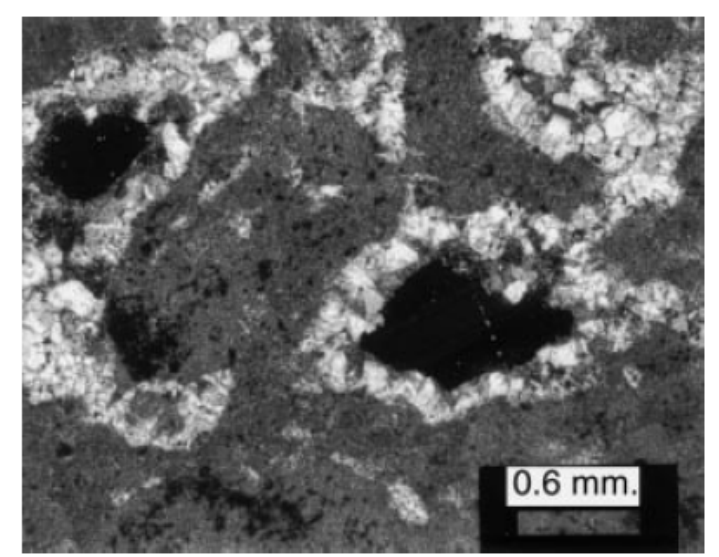

Fig. 9. Photomicrograph of porous carbonate facies showing dolomicrite (darker background in the photograph) with voids that are partly to totally cemented by calcite spar. The calcite spar mosaics are interpreted as a late diagenetic product after the degradation of previous tufa-like remains. clearly differentiated (Fig. 10A). These carbonates are formed exclusively of calcite and show the lightest values for both $\delta^{18} 0$ and $\delta^{13} \mathrm{C}$. Both massive dolomite and porous dolomite types have highly variable isotope compositions (mean of $\delta^{18} 0$ values $=0 \cdot 06$, standard deviation $=1 \cdot 75$; mean of $b^{13} \mathrm{C}$ values $=-3 \cdot 55$, sandard deviation $=1 \cdot 33$ ). Hwever, most of he $\delta^{18} 0$ values fall into a relatively narrow domain $(\approx-2 \%$ to $\approx 1 \cdot 50$ ), in which the massive dolomite and porous carbonate samples are not clearly differentiated. The same is seen in the distribution of $\delta^{13} \mathrm{C}$ values on the plot, despite the large spread of carbon isotope compositions (Fig. 10A). As shown in this figure, the isotopic compositions of the La Roda carbonates are clearly differentiated from other reported dolomites, such as those occurring in recent lacustrine environments from Australia (Rosen et al., 1989).

Both porous and massive dolomite samples show no significant relation of $\delta^{13} \mathrm{C}$ to $\delta^{18} 0$ $(r=-0 \cdot 05)$, so the isotopic compositions do not follow any simple trends. However, when examined in detail (Table 1), a more definite trend can be recognized, as many of the dolomite samples with heavy $\delta^{18} 0$ values are significantly depleted in heavy carbon. This is the case, for instance, in samples 1-04, 1-09, 1-10, 2-01, 2-02, 2-03 and 2-09 (Fig. 10B). The negative correlation between $\delta^{18} 0$ and $\delta^{13} \mathrm{C}$ values in the La Roda dolomites is clear 

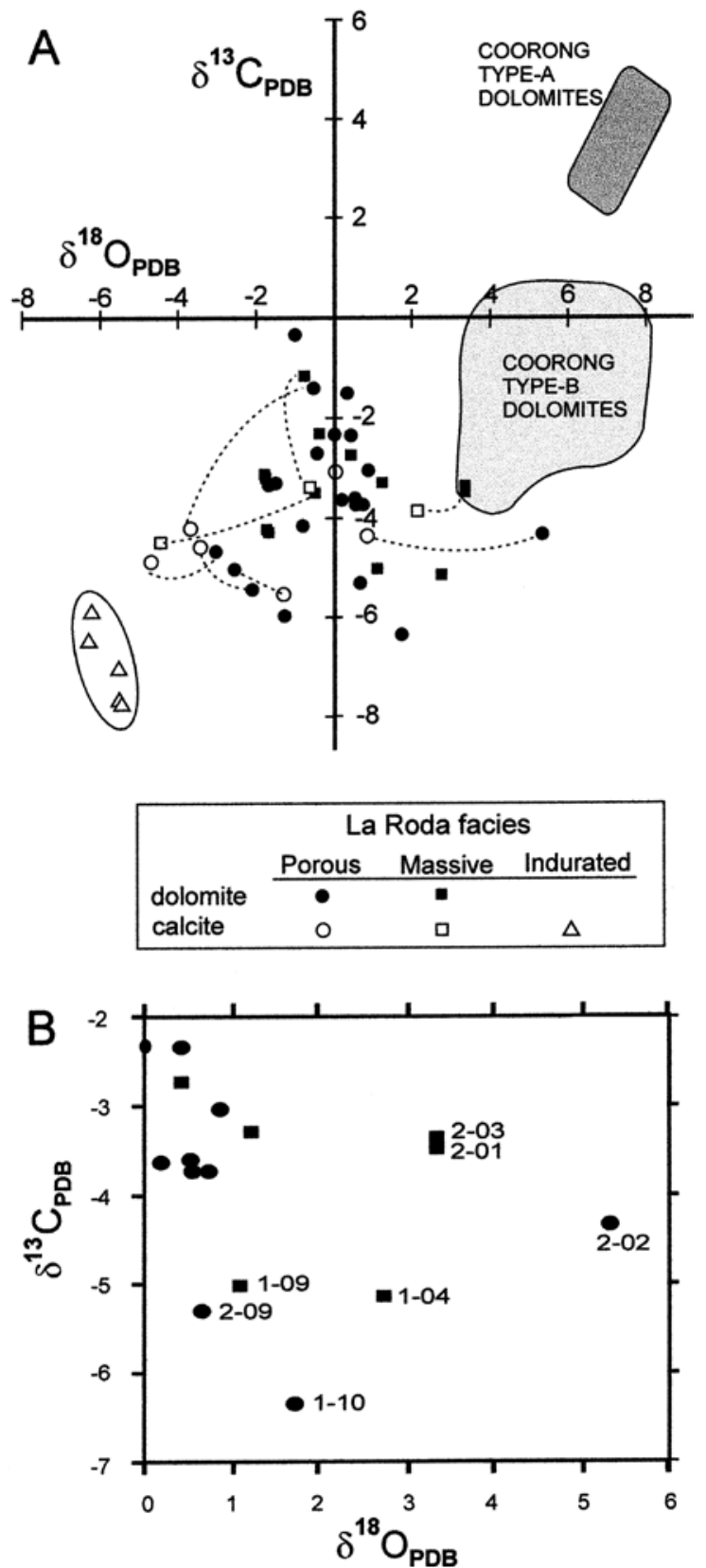

Fig. 10. (A) $\delta^{18} 0-\delta^{13} \mathrm{C}$ cross-plot for dolomite andc alcite samples from La Roda. Isotopic values determined in calcite from some bimineralic (dolomite-calcite) samples are also represented as pairs of samples linked by dashed lines. A field of samples showing very negative $b^{18} 0$ and $b^{13} C$ values (lower left) corresponds to samples of indurated limestones from the mudstonelimestone unit. Typical isotopic compositions of Coorong dolomites (Rosen et al., 1989) are shown. (B)

Close-up view of the lower right part of the $\delta^{18} 0-\delta^{13} \mathrm{C}$ cross-plot shown in (A); a negative correlation between $\delta^{18} 0$ and $\delta^{13} \mathrm{C}$ values is observed in the plot (see explanation in the text). in some samples, in which the presence of bacterial corpuscles has been recognized petrographically, which supports the influence of organic matter decomposition and, consequently, enrichment in ${ }^{12} \mathrm{C}$ in the formation of the dolomites (see discussion below).

The bimineralic samples show various trends with respect to enrichment or depletion in ${ }^{13} \mathrm{C}$ and ${ }^{18} 0$ between dolomite and calcite (Fig. 10A, Table 1). Thus, dolomite in samples 2-04 (massive dolomite) and 2-06 (porous carbonate) is significantly enriched in ${ }^{13} \mathrm{C}$ relative to calcite but shows similar ${ }^{18} 0$ compositions. More definite trends of ${ }^{18} 0$ enrichment (by 1.5-3.0\%o) of dolomite relative to calcite are observed in samples 2-01, 2-02, 5-05 and 5-07 (Table 1), in which variations in ${ }^{13} \mathrm{C}$ are not significant. Just one sample (6-04) shows an opposite pattern, i.e. calcite enriched in ${ }^{18} 0$ relative to dolomite, to the commonly observed trend.

\section{MODEL OF DOLOMITE FORMATION}

Geomorphology, hydrology and climatic setting of La Roda during the Late Pliocene

The carbonate deposits of the Pliocene dolomite unit of La Roda accumulated in a shallow, hydrologically closed perennial lake depression. Both the fluvial origin of the sandstones underlying the carbonates (Yébenes et al., 1973; Santos, 1983) and the evidence for shallowness shown by the deposits of the overlying mudstone-limestone unit support this interpretation. In addition, the massive character of the dolomite deposit and the presence of some subaerial exposure features, especially pedogenic disjunctions developed at the top of some sequences, suggest that the carbonates were deposited under shallow, probably oxic to suboxic bottom conditions (Anadón \& Utrilla, 1993). The actual extent of the depression in which the carbonates formed cannot be defined precisely, as the dolomite unit is covered by younger sedimentary formations, and no systematic drilling has been carried out beyond the quarries located around the village of La Roda. However, some local underground works (Santos, 1983) indicate that the stratigraphic unit containing the dolomites does not extend further than a few kilometres.

The area is surrounded by outcrops of Mesozoic carbonates in which dolostones predominate. Present-day groundwater systems in the region are mainly controlled by the distribution of the 
Mesozoic outcrops (D1az et al., 1990). In view of the slow evolution of the landscape in the region from the Pliocene to the present (Perez González, 1979), it appears that the hydrologic setting has not changed significantly, and the lake developed in La Roda during the Pliocene was fed according to a drainage pattern similar to that currently recognized: two groundwater basins converge from north and south in the La Roda area (Fig. 11). Leaching of the highly permeable Mesozoic carbonate rocks accounted

highly saturated $\mathrm{HCO}_{3}^{-} \mathrm{CO}^{2-}{ }_{3}$ groundwaters flowing into the lake depression, which behaved as a hydrologically closed lake basin. As indicated by data from drillholes in the area (Santos, 1983), the groundwaters stored in the Pliocene units of La Roda are the calcium-magnesium-sodium bicar- bonate type. Calculations of the saturation state of these waters, performed with the PHRQPITZ com- puter program (Plummer et al., 1988), indicate
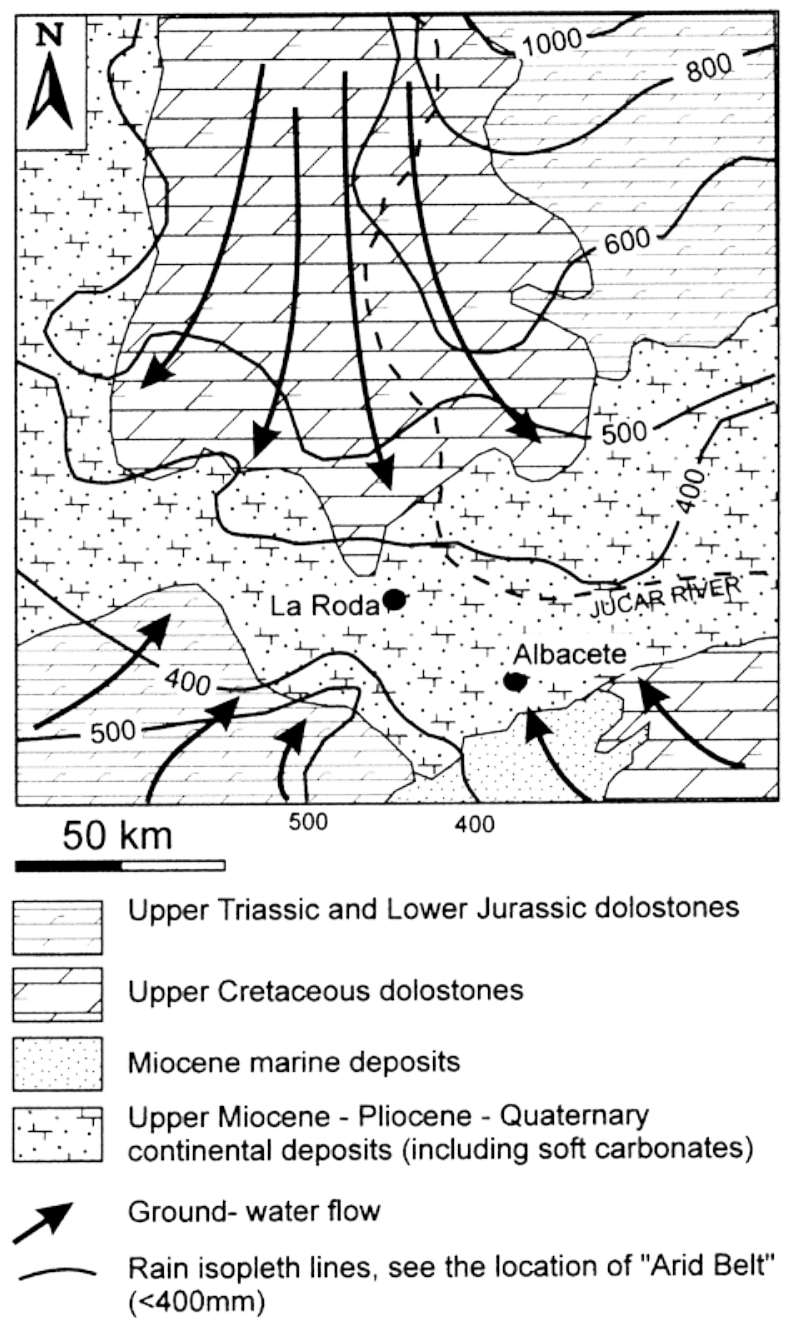

Fig. 11. Geological sketch showing the main regional for alkaline, that present-day waters are supersaturated with respect to dolomite and huntite, slightly saturated with respect to aragonite, calcite and magnesite, and undersaturated with respect to gypsum (Table 3 ).

Present-day regional climatic conditions of the La Roda area are characterized as arid to semiarid, with average annual precipitation varying between 300 and $400 \mathrm{~mm}$ and evaporation rates ranging from 400 to $500 \mathrm{~mm}$ (Dlaz et al., 1990; Ordó н еz et al., 1994); average temperatures

(4-6 ${ }^{\circ} \mathrm{C}$ in winter, $>30{ }^{\circ} \mathrm{C}$ in the summer period) are also characteristic of regions in an arid to semi-arid belt (Grove, 1977). Palaeoclimatic data inferred from the Late Pliocene stratigraphic record in areas adjacent to La Roda (Mein et al., 1978; Leone, 1985; Montuire, 1999) and those inferred from pollen data in the southern Mediterranean (Fauquette et al., 1999) indicate that climatic conditions during this period were variable, with several alternating warming (predominant) and cooling episodes. Variations in the climatic conditions of the area are recorded by the lithological changes observed between the two stratigraphic units present in La Roda. Thus, both the predominance of magnesium carbonate and the nature of the associated clays in the dolomite unit are in contrast to the abundance of terrigenous deposits and the freshwater nature of the limestones recognized in the mudstonelimestone unit. This suggests that warmer and dryer climatic conditions prevailed in the area during the deposition of the former unit, whereas more humid conditions prevailed during the accumulation of the latter unit.

Sedimentological model of dolomite formation

Field sedimentological analysis of the dolomite unit indicates that the two main facies present show a sequential arrangement. Massive dolomite, comprising most of the carbonate deposit, is present in the lower part of the sequences groundwater flow system in the La Roda area.

Table 3. Saturation index values (log IAP/K) at $25^{\circ} \mathrm{C}$ from groundwaters sampled in recent wells drilled in the La Roda area.

\begin{tabular}{lr}
\hline Aragonite & $1 \cdot 287$ \\
Calcite & $1 \cdot 307$ \\
Dolomite & $3 \cdot 068$ \\
Gypsum & $-4 \cdot 731$ \\
Huntite & $2 \cdot 809$ \\
Magnesite & $1 \cdot 160$
\end{tabular}


and grades transitionally upwards into porous carbonate. The sedimentary features observed in the latter facies (i.e. root traces, desiccation cracks, gypsum moulds and plant and/or biogenic remains) suggest that the dolomite deposit experienced some environmental change, perhaps as a result of shallowing and possibly relative freshening of the lake water. However, the porous carbonate is entirely dolomite, which provides evidence that, even at these stages, the concentration of water was enough to precipitate dolomite.

\section{Primary origin of dolomite}

The petrographic features shown by the dolomite deposits argue against a detrital origin for the dolomite. This is particularly evident in the massive dolomites in which the crystalline aggregates composed of interpenetrating submicron-sized dolomite grains indicate multiple growth episodes of the crystals (Rosen \& Coshell, 1992; Wright, 1999). The presence of these crystal morphologies together with euhedral dolomite in the porous carbonate also supports the authigenic character of the dolomite in this facies. However, the massive dolomites exhibit petrographic and mineralogical features that support a direct primary chemical precipitate origin. These features are: (i) the homogeneous compositional and textural character of the dolomite deposit; (ii) the absence of replacement textures, such as syntaxial, submicron calcite domains in the dolomite (Rosen et al., 1988); (iii) no petrographic evidence for partial dolomitization of biogenic calcite and/or aragonite precursors (Rosen \& Coshell, 1992); (iv) the small size $(1-2 \mu \mathrm{m})$ of the dolomite crystal aggregates, which also show mainly subhedral morphologies (De Deckker \& Last, 1989; Last \& De Deckker, 1990; Anadón \& Utrilla, 1993); and (v) the dolomites are calcium rich and poorly ordered, which is a commonly observed compositional characteristic of most primary lacustrine dolomites (Last, 1990; Last \& De Deckker, 1990).

Taking these petrographic and mineralogical features together, the massive dolomites from La Roda appear to have formed mainly as a direct precipitate from lake waters with an elevated carbonate/bicarbonate concentration, the carbon ate alkalinity being the factor that promotes the precipitation of dolomite, even though $\mathrm{Mg} / \mathrm{Ca}$ ratios are not high (Clayton et al., 1968; Hardie, 1987). As Hardie (1987) points out, a high $\mathrm{Mg} / \mathrm{Ca}$ ratio is not necessary to increase the dolomite solubility product when there is plenty of solute
$\mathrm{CO}_{3}^{2-}$ around, as illustrated at Deep Springs Lake where the ratio is near 1 (Jones, 1965). In this respect, the catchment drainage area of the La Roda palaeolake, underlain mainly by Mesozoic dolomite source rocks, implied a consistent rather than a concentrated groundwater source of $\mathrm{Mg}$.

Higher carbonate/bicarbonate concentrations and consequent increased alkalinity could have been derived from the relatively high temperatures prevailing in the arid to semi-arid region of La Roda for some periods throughout the Pliocene. Evaporative concentration, leading to saline lake conditions, has been commonly invoked as a decisive mechanism in controlling the formation of dolomite, especially in cases where primary dolomite is being formed (De Deckker \& Last, 1989; Rosen et al., 1989; Last, 1990; Warren, 1990). This is usually recorded by an enrichment in ${ }^{18} 0$ of the precipitated carbonate phases, which consequently show strong positive $\delta^{18} 0$ values (Rosen et al., 1988; Warren, 1990; Arenas et al., 1997). Dolomites from La Roda, however, show stable isotope compositions that are consistently lighter than those reported from evaporitic dolomites elsewhere (Fig. 10A). This suggests that the formation of the La Roda dolomites was promoted by moderate rather than strong evaporitic conditions. This contention is also supported by the scarcity or absence of preserved evaporites (i.e. Ca-sulphates) within the dolomite deposits. However, the absence of sulphate is not a conclusive criteria for discounting evaporitic conditions in the formation of dolomite, as sulphate can be removed by the activity of sulphate-reducing bacteria (Wright, 1999). The scatter of both oxygen and carbon isotopic values for dolomite, particularly for carbon, suggests some sort of mixing between meteoric and concentrated lake waters (Coniglio et al., 1988), a conclusion also reached by Rosen et al. (1989) for their type B dolomites from Coorong. Thus, the precipitation of dolomite in La Roda most probably resulted from mixing of evaporatively concentrated surface waters developed during short-term periods of drier climatic conditions and carbonate-rich groundwaters, leading to supersaturated carbonate/bicarbonate solutions in which dolomite precipitated directly or in interstitial pores. Under these conditions, lack of covariance of $\delta{ }^{18} 0$ and $\delta^{13} \mathrm{C}$ may be explained by the high carbonate alkalinity of the closedbasin ${ }_{13}$ lake, $\mathrm{t}$ he total $\mathrm{CO}_{2}$ concentration acting to damp the $\delta \mathrm{C}$ response to changes in water input and lake productivity (Li \& Ku, 1999). 
Petrographic evidence from the massive dolomite suggests an initial fine, gelatinous mud (consistency reminiscent of 'yoghurt') probably in the form of protodolomite (Von der Borch \& Lock, 1979), similar to that reported from recent dolomitic lake sediments (De Deckker \& Last, 1988). In this setting, both the submicron-sized grains of the dolomite aggregates and the low ordering of this mineral indicate that precipitation of dolomite is rapid (Wright, 1999).

Dolomite deposition took place probably under oxic to suboxic lake bottom conditions. This is supported by the absence of lamination in the dolomite deposit and can also be deduced from the negative correlation between Mn contents and the $\delta \mathrm{C}$ response to changes in water input and

lake productivity ( $\mathrm{Li} \& \mathrm{Ku}, 1999) .{ }^{13} \mathrm{C}$ values (Lohmann, 1988; Lumsden \& Lloyd, 1997; Fig. 8A). However, the inhibiting effect of

$\mathrm{SO}_{4}=$ anions on dolomite precipitation (Baker \& Kastner, 1981) is not considered a significant factor in the formation of dolomite in the La Roda palaeolake for the following reasons: (i) the presence of relics of sulphate minerals as calcite pseudomorphs after gypsum is restricted to a very few occurrences within the dolomite deposits; (ii) the composition of groundwater discharging in the region today is clearly undersaturated with respect to gypsum (see above); and (iii) observations in modern lakes in which dolomite is forming indicate that even relatively high sulphate levels of the brines do not seem to inhibit dolomite precipitation (De Deckker \& Last, 1988).

Formation of the La Roda dolomites under weakly evaporitic conditions is also supported by the mineralogy of the clays that occur associated with the carbonate sediments. Sepiolite is the main clay mineral within the dolomite deposits forming either thin clay interbeds or disseminated as small fibres within the dolomite aggregates (Fig. 5B); besides sepiolite, minor amounts of palygorskite, illite and kaolinite are also present. These latter clay minerals are probably detrital, whereas sepiolite is considered to be an authigenic clay mineral formed by direct precipitation from moderately saline lake water (Jones, 1986). In this respect, the absence of Mg-rich smectites (e.g. stevensite, saponite, kerolitestevensite, etc.) in the La Roda deposit helps to rule out a more saline environment (Khoury et al., 1982; Jones, 1986; Calvo et al., 1999; Chahi et al., 1999).

\section{Bacterial contribution to dolomite formation}

An alternative explanation for the scarcity or absence of sulphates in lacustrine dolomite deposits comes from the effect of sulphatereducing bacteria, which, in turn, would result in the removal of kinetic inhibitors to dolomite formation (Hardie, 1987; Wright, 1999). Moreover, bacterial activity, in either continental or marine depositional environments, has received recent attention as a mechanism involved in the formation of this mineral (Castanier et al., 1988; Vasconcelos et al., 1995; Vasconcelos \& McKenzie, 1997; Wright, 1997, 1999; Gournay et al., 1999; Burns et al., 2000).

The significance of the contribution of bacteria to dolomite formation is mainly based on laboratory experiments, recognition of microbial communities in recent dolomite-forming environments and petrographic evidence from modern and ancient dolomite deposits. The latter aspect has generated considerable literature about the textural features, usually based on SEM imagery, that provide evidence for the role of bacteria in the formation of carbonate (e.g. Buczynski \& Chafetz, 1991; Folk, 1993, 1999; Défarge et al., 1996). The most common petrographic evidence for the contribution of bacteria to the formation of dolomite, and carbonate in general, is the presence of minute elliptical or subrounded corpuscles that are interpreted to be fossilized bacterial bodies (Vasconcelos et al., 1995; Wright, 1999). Such features are clearly observed in some dolomite samples from La Roda (Fig. 5C), where the morphologies of grains covering dolomite crystal surfaces are quite representative of mineral encapsulation of bacterial cells. Besides this evidence, detailed observation at higher magnification of crystalline aggregates in the massive dolomites of La Roda (Fig. 5D) indicates that nannobacteria (sensu Folk, 1993, 1999) appear to be a major component involved in the formation of the dolomite aggregates. Accordingly, the coalescing of the submicron-sized grains would result in rather well-defined crystals whose morphologies clearly resemble those of the typical dolomite rhombs. The knobbly surfaces exhibited by the larger rhombs are probably produced by the presence of nannobacteria, an observation also made previously by Vasconcelos \& McKenzie (1997) from modern lake environments in Brazil. However, other crystalline aggregates forming the massive dolomites of La Roda do not show such clear 'bacterial appearance', although the presence of bacterial bodies is also suggested in local domains of the subcrystals (Fig. 5F). In this case, the better defined crystal faces could result from an increasing diagenetic self-organization of the initial minute mineralized bacterial bodies 
(Wright, 1999). This neomorphic process of crystal growth is in agreement with that reported from Holocene marine dolomites (Gregg et al., 1992), which suggests that recrystallization of dolomite begins immediately after its initial precipitation (Malone et al., 1994). Observations on the Pliocene continental dolomites of La Roda, which have not undergone any significant burial, could represent a good analogue for the recrystallization processes of dolomite reported from both continental and marine settings.

Further evidence for the contribution of bacteria to the formation of the La Roda dolomites derives from isotopic data determined for these deposits. Thus, the $\mathrm{b}^{13} \mathrm{C}$ values are relatively enriched in ${ }^{12} \mathrm{C}$, ranging from high $(-7 \cdot 720)$ to slightly negative (-0.390; Table 1 , Fig. 10B), which can be related to the decomposition of organic matter. An inorganic control on carbon isotope values should result in heavier $b^{13} \mathrm{C}$ values correlative with stronger evaporitic conditions during deposition of the dolomite (Rosen et al., 1989; Anadón \& Utrilla, 1993). However, the $b^{13} \mathrm{C}$ values characteristic of the carbonates that show typical pedogenic features (i.e. the indurated limestones group in Fig. 10A) are consistently lighter and clearly plot apart from the dolomite facies. Accordingly, the lighter $b^{13} \mathrm{C}$ values of the dolomites may result from organically influenced processes in which anaerobic bacteria were involved.

\section{DISCUSSION AND CONCLUDING REMARKS}

The deposits in La Roda provide an example of fossil lacustrine primary dolomites that accumulated in offshore areas of a shallow perennial lake undergoing episodic fluctuations in lake level. The deposits are relatively young (Upper Pliocene) and were not subjected to significant burial, which results in good preservation of their original depositional features. The homogeneous fabrics shown by the massive dolomites, characterized by small aggregates of dolomite crystals exhibiting poorly developed faces, suggest rapid precipitation from highly carbonate/bicarbonate concentrated lake waters. These conditions were apparently more stable in the offshore areas of the lake where relatively thick (up to $1 \mathrm{~m}$ ) dolomite beds, which show no significant variations in their structural and textural features, were deposited. Both the thickness and the massive character of the dolomites are similar to those reported from
Holocene lakes in Australia and North America in which offshore dolomite deposition has been recorded (Von der Borch \& Lock, 1979; De Deckker \& Last, 1988; Rosen et al., 1988; Last, 1990; and references therein; Last \& De Deckker, 1990; Wright, 1999). However, the stable isotope compositions of the La Roda dolomites differ from the $b^{13} C$ and $b^{18} 0$ values commonly determined in sediments characterized as 'evaporitic' primary dolomites (De Deckker \& Last, 1989; Rosen et al., 1989; Anadón \& Utrilla, 1993), suggesting that precipitation of dolomite in the La Roda palaeolake was strongly influenced by mixing between somewhat concentrated lake waters and meteoric waters supplied by groundwater flow. In this regard, it should be noted that the La Roda deposits are unique in lacking association with marine sulpho-chloride or sodic continental sediments. Thus, these lacustrine dolomites clearly reflect the predominance of the Mesozoic dolostones as a solute source.

0wing to a lack of well-exposed outcrops and drillhole documentation, the depositional model of La Roda fails, however, in the definition of the marginal areas of the lake system. In Holocene lake dolomite-forming environments, such as those of the south-eastern Australian region (e.g. Coorong, Pellet, Hayward, Pillie, central and western Victoria lakes; Last, 1990), the marginal lake areas commonly show a variety of lithologies that include both calcium (aragonite, low- and high-magnesian calcite) and magnesium-rich carbonates (hydromagnesite, magnesite, huntite, nesquehonite, dolomite), besides calcium and magnesium sulphates and chlorides (De Deckker, 1988; Warren, 1999) associated with marine aerosols. Thus, these marginal areas represent complex depositional environments in which the biogenic contribution by cyanobacterial mats and plants is noteworthy (De Deckker, 1988; Wright, 1999). In the La Roda deposits, the varied sedimentary association commonly recognized in recent marginal lake environments is probably represented by the porous carbonate facies interbedded with the massive dolomites, usually capping the carbonate sequences. Recognition of biogenic structures, root-related fabrics, desiccation cracks and occasional moulds of lenticular gypsum within the porous carbonate indicates that this facies formed under shallower lake levels (even subaerial) than the massive dolomite. Accordingly, the porous carbonate facies is similar to sediments forming in lake margin areas at the time when the offshore dolomites accumulated. This interpretation is compatible with 
similar mineralogical, geochemical and isotopic compositions for the porous carbonate and the massive dolomite.

The presence and amount of organic matter in the original dolomite deposits remains an open question. The bright white colour (witness the name 'white earth' used for these materials) of the dolomite beds suggests net oxidizing conditions during or after the formation of the dolomites. Many reported occurrences of recent lacustrine sediments are associated with variable amounts of organic matter present as disseminated organic particles or as interbedded organic-rich horizons (De Deckker, 1988; Vasconcelos \& McKenzie, 1997). However, organic matter is easily lost by oxidation when the deposit remains near the surface, which was apparently the case for the La Roda dolomite deposits. 0xidation of organic matter leading to a drastic diagenetic change from dark or brownish colours into a pure white sediment has been documented in other organicrich lacustrine deposits, such as diatomite (Calvo et al., 1998). At least some organic matter was originally present within the lake sediments of La Roda, as indicated by abundant bacterial morphologies in the carbonate crystals, which provide evidence that dolomite growth was influenced by microbial activity. In conclusion, high alkalinity and bacterial agents are thought to have been the most important factors involved in the formation of the La Roda dolomites.

\section{ACKNOWLEDGEMENTS}

The authors are indebted to David Benavente (University of Alicante) for helping in computer treatment of data, and to Alfonso Rodriguez (Electronic Microscopy Centre, UCM) and Andrés Amorós (UA) for their assistance with SEM imagery. We also thank Jessica Hopple in Tyler Coplen's laboratory at the USGS for aid with isotopic analyses. We are grateful to Sedimentology reviewers Dr Robert Folk and Dr William Last for their encouraging comments, and to Dr Peter Mozley for his careful editorial work. Funding for this work was provided by the Direccion General de Enser anza Superior of Spain through project PB97-0244.

\section{REFERENCES}

Anadón, P. and Utrilla, R. (1993) Sedimentology and isotope geochemistry of lacustrine carbonates of the oligocene
Campins Basin, north-east Spain. Sedimentology, 40, 699720.

Arenas, C., Casanova, J. and Pardo, G. (1997) Stable-isotope characterization of the Miocene lacustrine systems of Los Monegros (Ebro Basin, Spain): palaeogeographic and palaeoclimatic implications. Palaeogeogr. Palaeoclimatol. Palaeoecol., 128, 133-155.

Arvidson, R.S. and Mackenzie, F.T. (1999) The dolomite problem: control of precipitation kinetics by temperature and saturation state. Am. f. Sci., 299, 257-288.

Baker, P.A. and Kastner, M. (1981) Constraints on the formation of sedimentary dolomites. Science, 213, 214-216.

Bathurst, R.G.C. (1975) Carbonate Sediments and Their Diagenesis. Developments in Sedimentology 12. Elsevier, Amsterdam, 658 pp.

Buczynski, C. and Chafetz, H.S. (1991) Habit of bacterially induced precipitates of calcium carbonate and the influence of medium viscosity on mineralogy. f. Sed. Petrol., 61, 226-233.

Burns, S.J., Mckenzie, J.A. and Vasconcelos, C. (2000) Dolomite formation and biogeochemical cycles in the Phanerozoic. Sedimentology, 47 (Suppl. 1), 49-61.

Calvo, J.P., Rodriguez-Pascua, M.A., Martin-Velázquez, S., Jiménez, S. and De Vicente, G. (1998) Microdeformation of lacustrine laminite sequences from Late Miocene formations of SE Spain: an interpretation of loop bedding. Sedimentology, 45, 279-292.

Calvo, J.P., Blanc-Valleron, M.M., Rodriguez-Aranda, J.P., Rouchy, J.M. and Sanz, M.E. (1999) Authigenic clay minerals in continental evaporitic environments. Int. Assoc. Sedimentol. Spec. Publ., 27, 129-151.

Castanier, S., Maurin, A. and Perthuisot, J.P. (1988) Les Cugnites: carbonates amorphes de Ca et Mg, precurseurs possibles de la dolomite. CR Acad. Sci. Paris, 306, 1231-1235.

Chahi, A., Duringer, P., Ais, M., Bouabdelli, M., GauthierLafaye, F. and Fritz, B. (1999) Diagenetic transformation of dolomite into stevensite in lacustrine sediments from Jbel Rhassoul, Morocco.f. Sed. Res., 69, 1123-1135.

Chilingar, G.V., Zenger, D.H., Bissell, H.L. and Wolf, K.H. (1979) Dolomites and dolomitization. In: Diagenesis in Sediments and Sedimentary Rocks (Eds G. Larsen and G.V. Chilingar). Developments in Sedimentology 25A, pp. 425436. Elsevier, Amsterdam.

Clayton, R.N., Jones, B.F. and Berner, R.A. (1968) Isotope studies of dolomite formation under sedimentary conditions. Geochim. Cosmochim. Acta, 32, 415-432.

Coniglio, M., James, N.P. and Aissaoui, D.M. (1988) Dolomitization of Miocene carbonates, Gulf of Suez, Egypt. f. Sed. Petrol., 58, 100-119.

Craig, H. (1957) Isotopic standards for carbon and oxygen and correction factors for mass-spectrometric analysis of carbon dioxide. Geochim. Cosmochim. Acta, 12, 133-149.

De Deckker, P. (1988) Biological and sedimentary facies of Australian salt lakes. Palaeogeogr. Palaeoclimatol. Palaeoecol., 62, 237-270.

De Deckker, P. and Last, W.M. (1988) Modern dolomite deposition in continental, saline lakes, western Victoria, Australia. Geology, 16, 29-32.

De Deckker, P. and Last, W.M. (1989) Modern, non-marine dolomite in evaporitic playas of western Victoria, Australia. Sed. Geol., 64, 223-238.

Défarge, C., Trichet, J., Jaunet, A.M., Michel, R., Tribble, J. and Sansone, F.J. (1996) Texture of microbial sediments revealed by electron microscopy. f. Sed. Res., 66, 935-947. 
Diaz, J.L., Sierra, J., Vázquez, A. and Zárate, A. (1990) Atlas de Castilla-La Mancha. Servicio de Publicaciones de la Junta de Comunidades de Castilla-La Mancha, Toledo, 127 pp.

Eugster, H.P. and Hardie, L.A. (1978) Saline lakes. In: Lakes Chemistry, Geology, Physics (Ed. A. Lerman), pp. 237-293. Springer-Verlag, New York.

Eugster, H.P. and Kelts, K. (1983) Lacustrine chemical sediments. In: Chemical Sediments and Geomorphology (Eds A.S. Goudie and K. Pye), pp. 321-368. Academic Press, London.

Fairbridge, R.W. (1957) The dolomite question. In: Regional Aspects of Carbonate Deposition (Eds R.J. LeBlanc and J.G. Breeding), SEPM Spec. Publ., 5, 124-178.

Fauquette, S., Suc, J.P., Guiot, J., Diniz, F., Feddi, N., Zheng, Z., Bessais, E. and Drivaliari, A. (1999) Climate and biomes in the West Mediterranean area during the Pliocene. Palaeogeogr. Palaeoclimatol. Palaeoecol., 152, 15-36.

Folk, R.L. (1993) SEM imaging of bacteria and nannobacteria in carbonate sediments and rocks. f. Sed. Petrol., 63, 990-999.

Folk, R.L. (1999) Nannobacteria and the precipitation of carbonate in unusual environments. Sed. Geol., 126, 47-55.

Franzini, M., Leoni, L. and Saitta, M. (1972) A simple method to evaluate the matrix in $\mathrm{x}$-ray fluorescence analysis. $X$-ray Spectrom., 1, 151-154.

Franzini, M., Leoni, L. and Saitta, M. (1976) Enhancement effects in x-ray fluorescence analysis of rocks. $X$-ray Spectrom., 5, 208-211.

Goldsmith, J.R. and Graf, D.L. (1958) Relations between lattice constraints and composition of the Ca-Mg carbonates. Am. Mineral., 43, 84-101.

Goldsmith, J.R., Graf, D.L. and Heard, H.C. (1961) Lattice constants of the calcium-magnesium carbonates. Am. Mineral., 46, 453-457.

Gournay, J.P., Kirkland, B.L., Folk, R.L. and Lynch, F.L. (1999) Nanometer-scale features in dolomite from Pennsylvanian rocks, Paradox Basin, Utah. Sed. Geol., 126, 243252.

Gregg, J.M., Howard, S.A. and Mazzullo, S.J. (1992) Early diagenetic recrystallization of Holocene $(<3000$ years old $)$ peritidal dolomites, Ambergis Cay, Belize. Sedimentology, $39,143-160$.

Grove, A.T. (1977) The geography of semi-arid lands. Phil. Trans. Roy. Soc. London, B178, 457-475.

Gunatilaka, A. (1987) The dolomite problem in light of recent studies. Modern Geol., 11, 311-324.

Hardie, L.A. (1987) Dolomitization: a critical view of some current views. f. Sed. Petrol., 57, 166-183.

Hardy, R.G. and Tucker, M.E. (1988) X-ray powder diffraction of sediments. In: Techniques in Sedimentology (Ed. M.E. Tucker), pp. 191-228. Blackwell Science Publishers, 0xford.

Jones, B.F. (1965) The hydrology and mineralogy of Deep Springs Lake, Inyo County, California. US Geol. Surv. Prof. Pap., 502-A, 56 pp.

Jones, B.F. (1986) Clay mineral diagenesis in lacustrine sediments. In: Studies in Diagenesis (Ed. F.A. Mumpton), US Geol. Surv. Bull., 1578, 291-300.

Katz, A. and Matthews, A. (1977) The dolomitization of $\mathrm{CaCO}_{3}$ : an experimental study at $252-295^{\circ} \mathrm{C}$. Geochim. Cosmochim. Acta, 41, 297-308.

Khoury, H.N., Eberl, D.D. and Jones, B.F. (1982) Origin of magnesium clays from the Amargosa Desert, Nevada. Clay Clay Mineral., 30, 327-336.
Kretz, R. (1982) A model for the distribution of trace elements between calcite and dolomite. Geochim. Cosmochim. Acta, $46,1979-1981$.

Land, L.S. (1985) The origin of massive dolomite. f. Geol. Educ., 33, 112-125.

Last, W.M. (1990) Lacustrine dolomite - an overview of modern, Holocene, and Pleistocene occurrences. Earth-Sci. Rev., 27, 221-263.

Last, W.M. and De Deckker, P. (1990) Modern and Holocene carbonate sedimentology of two saline volcanic maar lakes, southern Australia. Sedimentology, 37, 967-981.

Leone, G. (1985) Paleoclimatology of the Casas del Rincon Villafranchian Series (Spain) from stable isotope data. Palaeogeogr. Palaeoclimatol. Palaeoecol., 49, 61-77.

$\mathrm{Li}, \mathrm{H} . \mathrm{C}$. and $\mathrm{Ku}, \mathrm{T} . \mathrm{L}$. (1999) $\mathrm{b}^{13} \mathrm{C}$ and $\mathrm{b}^{18} 0$ covariance as a paleohydrological indicator for closed-basin lakes. Palaeogeogr. Palaeoclimatol. Palaeoecol., 133, 69-80.

Lindholm, R.C. and Finkelman, R.B. (1972) Calcite staining: semiquantitative determination of ferrous iron. $f$. Sed. Petrol., 42, 239-245.

Lippman, F. (1973) Sedimentary Carbonate Minerals. Springer-Verlag, New York, 219 pp.

Lohmann, K.C. (1988) Geochemical patterns of meteoric diagenetic systems and their application to paleokarst. In: Paleokarst (Eds. P.W. Choquette and N.P. James), pp. 58-80. Springer-Verlag, New York.

Lumsden, D.N. and Lloyd, R.V. (1997) Three dolomites. f. Sed. Res., 67, 391-396.

Machel, H.G. and Mountjoy, E.W. (1986) Chemistry and environments of dolomitization. Earth-Sci. Rev., 23, 175-222.

Malone, M.J., Baker, P.A. and Burns, S.J. (1994) Recrystallization of dolomite: evidence from the Monterey Formation (Miocene), California. Sedimentology, 41, 1223-1239.

Mein, P., Moissenet, E. and Truc, G. (1978) Les formations continentales du Néogene supérieur des vallees du Jucar et du Cabriel au NE d'Albacete (Espagne). Biostratigraphie et environnement. Doc. Lab. Géol. Fac. Sci. Lyon, 72, 99-147.

Montuire, S. (1999) Mammalian faunas as indicators of environmental and climatic changes in Spain during the Pliocene-Quaternary transition. Quatern. Res., 52, 129-137.

Morrow, D.W. (1982a) Diagenesis 1. Dolomite. Part 1: The chemistry of dolomitization and dolomite precipitation. Geosci. Can., 9, 5-13.

Morrow, D.W. (1982b) Diagenesis 2. Dolomite. Part 2: Dolomitization models and ancient dolostone. Geosci. Can., 9, 95-107.

Müller, G., Irion, G. and Forstner, U. (1972) Formation and diagenesis of inorganic Ca-Mg carbonates in the lacustrine environment. Naturwissenschaften, 59, 158-164.

Ordónez, S., Sánchez Moral, S., Garcia del Cura, M.A. and Rodriguez Badiola, E. (1994) Precipitation of salts from $\mathrm{Mg}^{2+}-\left(\mathrm{Na}^{+}\right)-\mathrm{SO}_{4}^{2-} \mathrm{Cl}^{-}$playa-lake brines: the endorheic saline ponds of La Mancha, central Spain. In: Sedimentology and Geochemistry of Modern and Ancient Saline Lakes (Eds R.W. Renaut and W.M. Last), SEPM Spec. Publ., 50, 61-71.

Pérez González, A. (1979) Neógeno y Cuaternario de la Llanura Manchega y sus relaciones con la Cuenca del Tajo. PhD Thesis, Universidad Complutense, Madrid, 787 pp.

Plummer, L.N., Parkhurst, D.L., Flemming, G.W. and Dunkle, S.A. (1988) PHRQPITZ, a computer program incorporating Pitzer's equations for calculation of geochemical reactions in brines. US Geol. Surv. Water Res., 88-4153, 310 pp.

Rosen, M.R. and Coshell, L. (1992) A new location of Holocene dolomite formation, Lake Hayward, Western Australia. Sedimentology, 39, 161-166. 
Rosen, M.R., Miser, D.E. and Warren, J.K. (1988) Sedimentology, mineralogy and isotopic analysis of Pellet Lake, Coorong Region, South Australia. Sedimentology, 35, 105122.

Rosen, M.R., Miser, D.E., Starcher, M.A. and Warren, J.K. (1989) Formation of dolomite in the Coorong region, South Australia. Geochim. Cosmochim. Acta, 53, 661-669.

Santos, J.A. (1983) Estudio geoquImico y sedimentológico del Terciario continental de la Cuenca del fúcar (provincia de Albacete). PhD Thesis, Universidad Complutense, Madrid, 508 pp.

Smoot, J.P. (1983) Depositional subenvironments in an arid closed basin; the Wilkins Peak Member of the Green River Formation (Eocene), Wyoming. Sedimentology, 30, 801828.

Talbot, M.R. and Kelts, K. (1986) Primary and diagenetic carbonates in the anoxic sediments of Lake Bosumtwi, Ghana. Geology, 14, 912-916.

Tucker, M.E. and Wright, V.P. (1990) Carbonate Sedimentology. Blackwell Science Publishers, 0xford, 482 pp.

Vasconcelos, C. and McKenzie, J.A. (1997) Microbial mediation of modern dolomite precipitation and diagenesis under anoxic conditions (Lagoa Vermelha, Rio de Janeiro, Brazil). f. Sed. Res., 67, 378-390.

Vasconcelos, C., McKenzie, J.A., Bernasconi, S., Grujic, D. and Tien, A.J. (1995) Microbial mediation as a possible mechanism for natural dolomite formation at low temperatures. Nature, 377, 220-222.

Von der Borch, C.C. and Lock, D. (1979) Geological significance of Coorong dolomites. Sedimentology, 26, 813-824.
Warren, J.K. (1989) Evaporite Sedimentology. Prentice Hall, Englewood Cliffs, NJ, 285 pp.

Warren, J.K. (1990) Sedimentology and mineralogy of dolomitic Coorong lakes, South Australia. f. Sed. Petrol., 60, 843858.

Warren, J.K. (1999) Evaporites. Their Evolution and Economics. Blackwell Science, 0xford, 483 pp.

Wolfbauer, C.A. and Surdam, R.C. (1974) Origin of nonmarine dolomite in Eocene Lake Gosiute, Green River Basin, Wyoming. Geol. Soc. Am. Bull., 85, 1733-1740.

Wright, D.T. (1997) An organogenic origin for widespread dolomite in the Cambrian Eilean Dubh Formation, northwestern Scotland. f. Sed. Res., 67, 54-64.

Wright, D.T.(1999) The role of sulphate-reducing bacteria and cyanobacteria in dolomite formation in distal ephemeral lakes of the Coorong region, South Australia. Sed. Geol., 126, 147-157.

Y'ébenes, A., de la Ренa, J.A. and Ordónez, S. (1973) Sedimentos dolom'lticos para-actuales: la 'Tierra Blanca' de La Roda (Albacete). Estud. Geol., 29, 343-349.

Zenger, D.H. (1972) Significance of supratidal dolomitization in the geological record. Geol. Soc. Am. Bull., 83, 1-12.

Zenger, D.H., Dunham, J.B. and Ethington, R.L. (eds) (1980) Concepts and models of dolomitization. SEPM Spec. Publ., 28, 320 pp. 